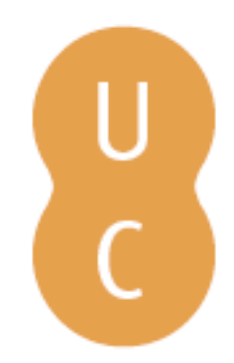

\title{
pommalina
}

\section{Reflexões sobre a obrigação de alimentos entre ex-cônjuges}

Autor(es): $\quad$ Tomé, Maria João Romão Carreiro Vaz

Publicado por: Imprensa da Universidade de Coimbra

URL

persistente: URI:http://hdl.handle.net/10316.2/38895

DOI: $\quad$ DOI:http://dx.doi.org/10.14195/978-989-26-1113-6_17

Accessed : $\quad$ 26-Apr-2023 10:21:24

A navegação consulta e descarregamento dos títulos inseridos nas Bibliotecas Digitais UC Digitalis, UC Pombalina e UC Impactum, pressupõem a aceitação plena e sem reservas dos Termos e Condições de Uso destas Bibliotecas Digitais, disponíveis em https://digitalis.uc.pt/pt-pt/termos.

Conforme exposto nos referidos Termos e Condições de Uso, o descarregamento de títulos de acesso restrito requer uma licença válida de autorização devendo o utilizador aceder ao(s) documento(s) a partir de um endereço de IP da instituição detentora da supramencionada licença.

Ao utilizador é apenas permitido o descarregamento para uso pessoal, pelo que o emprego do(s) título(s) descarregado(s) para outro fim, designadamente comercial, carece de autorização do respetivo autor ou editor da obra.

Na medida em que todas as obras da UC Digitalis se encontram protegidas pelo Código do Direito de Autor e Direitos Conexos e demais legislação aplicável, toda a cópia, parcial ou total, deste documento, nos casos em que é legalmente admitida, deverá conter ou fazer-se acompanhar por este aviso.

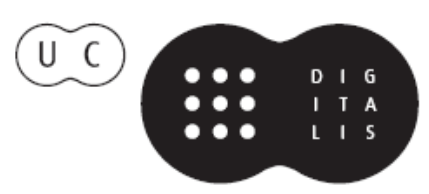




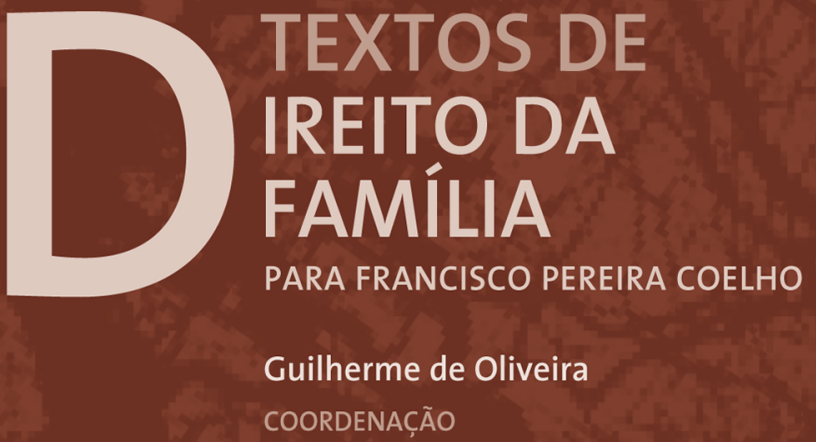




\section{REFLEXÕ ES SOBRE A OBRIGAÇÃO DE ALIMENTOS ENTRE EX-CÔNJUGES ${ }^{1}$}

Maria João Romão Carreiro Vaz Tomé Faculdade de Direito da Universidade Católica Portuguesa, Porto

\section{Sumário}

1. Introdução; 2. A obrigação de alimentos entre ex-cônjuges; 2.1. Fundamento; 2.2. Natureza; 2.3. Modelo alimentar; 2.4. Pressupostos; 2.5. Carácter temporário; 2.6. Art. $2016 .^{\circ}-\mathrm{A}, \mathrm{n} .{ }^{\circ}$ 3; 2.7. Art. $2016 .^{\circ}$-A, n. ${ }^{\circ} 1 ; 2.8$. Art. 2016. ${ }^{\circ}$ A, n. ${ }^{\circ} 2 ; 2.9$. Alteração; 2.10. Algumas causas de cessação; 3. Conclusão.

\section{Introdução}

Toda e qualquer sociedade se depara com a necessidade de assegurar a existência dos seus membros. A construção jurídico-familiar da segurança de existência da mulher divorciada constitui o objecto

\footnotetext{
${ }^{1}$ Neste texto de comemoração do nonagésimo aniversário do insigne Professor Doutor Francisco Manuel Pereira Coelho, não posso deixar de evocar a imagem de excelência que, como Professor, cultor daquela liberdade de pensamento característica da Universitas e de uma construção humanista do Direito, assim como de inteireza que, como Homem, deixou na memória de todos os que se sentaram nos bancos da sua Escola.

Revisito, neste estudo, o tema do relatório que apresentei na disciplina de Direito da Família, por si lecionada no Mestrado em Ciências Jurídico-Civilísticas.
} 
deste estudo. O tema é tratado apenas à luz da obrigação de alimentos do direito civil da família, não se levando em linha de conta a ordem jurídica na sua globalidade. $O$ direito civil e o direito da segurança social representam sistemas essenciais da segurança de existência ${ }^{2}$. Não se aborda a questão de se saber se a segurança de existência é melhor assegurada no direito civil ou no direito da segurança social, assim como não se visa identificar, no universo de normas vigentes, a presença de princípios unificadores e sistematizadores - ou a sua ausência. A construção sistemática e dogmática apresentam uma dificuldade especial no direito da segurança social, sobretudo em virtude das características das matérias reguladas. Escassas têm sido as preocupações sobre a relação entre o direito civil e o direito social.

$O$ direito vigente parece responder mais a exigências de uma política para os indivíduos que integram o grupo familiar, mesmo que em crise, por motivos relacionais (pense-se nas patologias da relação conjugal) ou por condições pessoais (refiram-se os idosos), do que a imposições de uma política da família, destinada a promover, juntamente com os interesses do grupo familiar, a pessoa de cada um dos indivíduos que a compõem.

A evolução do direito civil da família tem sido no sentido de uma progressiva emancipação do indivíduo no seio do grupo familiar, com as consequentes permeabilidade do direito a volições individuais e compressão das exigências da família enquanto formação social. Refira-se, a este propósito, a afirmação do primado da liberdade do indivíduo. Assim, a afectividade e a desinstitucionalização como que representaram "revoluções copérnicas" do direito civil da família. Uma pretensão de incremento de autenticidade e de felicidade con-

${ }^{2}$ Cfr. FUCHS, M., Zivilrecht und Sozialrecht, Recht und Dogmatik materiel- ler Existenzsicherung in der modernen Gesellschaft, C.H. Beck'sche Verlagsbuch- handlung, Muenchen, 1992, p. 2. 
duziram como que a uma absolutização da afectividade, como que a uma redução do vínculo jurídico a um aliquid voluntatis ${ }^{3}$.

A tarefa do legislador consiste agora, sobretudo, na articulação das consequências do divórcio, de modo a assegurar, tanto quanto possível, o máximo de protecção dos sujeitos considerados merecedores de especial tutela, com o mínimo de sacrifício de tal liberdade. Compete-lhe também conformar aquela solidariedade patrimonial que encontra na comunhão conjugal a sua mais forte afirmação. Tal como no passado, o direito da família é visivelmente influenciado por preocupações de ordem económica, agora, porém, tendencialmente em torno do indivíduo e não tanto da unidade familiar ${ }^{4}$.

\footnotetext{
3 A debilitação dos vínculos e das relações de autoridade desembocou num certo contratualismo: a direcção da família é atribuída à autonomia dos cônjuges (o exercício das responsabilidades parentais, a fixação do nível de vida familiar, o domicílio, etc.). Em geral, este movimento é caracterizado pela substituição gradual da imposições estandardizadas do Estado pela escolha individual no que toca à natureza, à duração e aos termos da relação conjugal (o que não se verifica na ordem jurídica portuguesa, em que o casamento continua a ser objecto de estrita regulamentação legal no que respeita aos seus requisitos de fundo e de forma, assim como aos seus efeitos pessoais e patrimoniais, não podendo os direitos e deveres pessoais dos cônjuges ser objecto de convenção antenupcial - art. 1699. ${ }^{\circ}$, n. ${ }^{\circ}$ 1, al. a), do Cód. Civil). Cfr. FranCisco MANuel Pereira Coelho, Casamento e Família no Direito Português, in Temas de Direito da Família, Coimbra, 1986, p. 24; GUILHERME DE OLIVEIRA, Observações sobre os regimes de bens, in Temas de Direito da Família, Coimbra, 1986, p. 254; MARTHA AlBERTSOn FInEMAN, The Illusion of Equality - the Rethoric and Reality of Divorce Reform, Chicago London, 1991, p. 16 e ss.; HEINRICH EWALD HÖRSTER, Direito da Família, in Polis - Direito Económico - Direito da Família, c. 448; JOÃo PAUlo REMÉdIO MARQUES, Algumas notas sobre alimentos (devidos a menores) "versus" o dever de assistência dos pais para com os filhos (em especial filhos menores), Faculdade de Direito da Universidade de Coimbra, Centro de Direito da Família, Coimbra Editora, Coimbra, 2000, p. 13; MARIA JOÃO VAZ TOMÉ, O direito à pensão de reforma enquanto bem comum do casal, Coimbra Editora, Coimbra, 1997, p. 128 e ss.; Cfr. MARIA JOÃO VAZ TOMÉ, O direito à pensão de reforma (por velhice) no divórcio - algumas considerações, Tribunal de Contas, Seminário "Direito da Segurança Social", Lisboa, 2000, p. 150 e ss.

${ }^{4} \mathrm{~A}$ instabilidade da família conjugal refere-se à facilidade com que os indivíduos podem entrar e sair dela e não tanto à qualidade dos seus laços afectivos (enquanto duram). A instabilidade e a fluidez que caracterizam as relações pessoais mais próximas resultam, principalmente, não da morte, mas antes do exercício da escolha agora possível em virtude das oportunidades que os indivíduos têm de encontrar apoio económico fora da família.
} 
Por seu turno, o divórcio igualitário como que gera um paradxo: o cônjuge economicamente mais vulnerável, que aderiu a um ideal de paridade no casamento, no momento em que este se dissolve poderá ver-se confrontado com a necessidade de apresentar preten-

O vínculo conjugal era relativamente duradouro (qual consortium omnis vitae) quando a família funcionava simultaneamente como unidade de trabalho, de produção e de consumo. A perda de funções políticas e económicas sofrida pela família parece ser uma consequência da passagem de uma sociedade agrícola para uma sociedade industrial dotada de enorme desenvolvimento do sector terciário e, assim, da intensificação da divisão social do trabalho e da transição da grande para a pequena família. Demitida das suas funções tradicionais, reduzida na sua consistência numérica e limitada ao papel educativo e cultural, a família tem, como principal função o suporte afectivo dos seus membros. Cfr. FRANCISCO MANUEL Pereira COELHO, Curso de Direito da Família, Coimbra, 1986, p. 60; JOÃo DE MATOS ANTUNES VAREla, Evolução histórica da sociedade familiar, in Direito e Justiça, 1981/1986, 2, p. 40-42; DIOGO LEITE DE CAMPOS, Lições de Direito da Família e de Direito das Sucessões, Coimbra, Almedina, 1990, p. 55; Cfr. MARIA JOÃO VAZ TOMÉ, O direito à pensão de reforma (por velbice) no divórcio - algumas considerações, Tribunal de Contas, Seminário "Direito da Segurança Social", Lisboa, 2000, p. 150 e ss.

O direito da segurança social penetrou no grupo familiar, pois que na época contemporânea e nas sociedades industrializadas a família não consegue assegurar cabalmente a segurança dos seus membros. O direito da segurança social desonera a família da tarefa de assegurar a sobrevivência dos seus componentes, permitindo-lhes procurar a "felicidade" (individual, antes de tudo) e tornar-se o "lugar da felicidade". Aumentou a dependência do indivíduo perante o Estado ao mesmo tempo que diminuiu a dependência do indivíduo perante a família. Compreendendo funções que a família exercia antes em benefício dos seus membros, as instituições da segurança social substituíram-se ao grupo familiar, transformando a estrutura deste grupo assim como as relações jurídicas que unem entre si os membros da família. Todavia, mesmo na hipótese de uma plena concretização do desenho constitucional da segurança social, deve reconhecer-se que a intervenção do Estado ou de outras entidades não pode ocupar o espaço destinado às várias formas de solidariedade familiar. A tal obsta o reconhecimento formal dos direitos da família (arts. $36 .^{\circ}$, n. $^{\text {os }} 1-6$, e $67 .^{\circ}$ da Constituição) que, apesar de limitado à "família nuclear", não consente perspectivar a solidariedade familiar numa relação de alternatividade ou de subsidariedade com as formas de solidariedade realizadas pela colectividade no sistema da segurança social. A separação entre vida profissional e vida familiar desenvolveu-se em simbiose com a privatização da família. Esta privatização constitui, em larga medida, a contrapartida da socialização das funções de segurança. A segurança passou de familiar a social. Cfr. JOÃO PAULO REMÉDIO MARQUES, Algumas notas sobre alimentos (devidos a menores) "versus" o dever de assistência dos pais para com os filhos (em especial filhos menores), Faculdade de Direito da Universidade de Coimbra, Centro de Direito da Família, Coimbra Editora, Coimbra, 2000, p. 11 e e ss.; MARIA JOÃO VAZ TOMÉ, $O$ direito à pensão de reforma enquanto bem comum do casal, Coimbra Editora, Coimbra, 1997, p. 137 e ss.; MARIA JOÃO VAZ TOMÉ, O direito à pensão de reforma (por velhice) no divórcio - algumas considerações, Tribunal de Contas, Seminário "Direito da Segurança Social", Lisboa, 2000, p. 150 e ss. 
sões baseadas no seu papel tradicional de sujeito economicamente dependente 5 .

A partir do momento em que se pretende depurar a regulamentação do divórcio - quer nos seus pressupostos, quer nos seus efeitos - de qualquer elemento sancionatório, o legislador depara-se com a necessidade de resolver o problema da tutela existencial do ex-cônjuge economicamente mais vulnerável no âmbito da solidariedade social, como consequência radical da extinção da relação conjugal, ou mediante o recurso a uma solidariedade pós-conjugal. Na medida em que a adopção da primeira proposta se afigura, pelo menos, de praticabilidade muito difícil - porque extremamente gravosa para a colectividade -, resta lançar mão de uma espécie de ultra-actividade da solidariedade conjugal como fundamento da atribuição do direito a alimentos. Acresce que a crise - e consequente metamorfose - do Estado Social demonstra que o Estado não tem capacidade para se substituir à família ${ }^{6}$ que é, em si mesma, também uma comunidade de solidariedade.

No direito da família, em geral e, em particular, no que toca às crises familiares, o legislador depara-se com a dificuldade representada pelas delicadas mediações ideológicas e sociais que lhe são exigidas numa sociedade complexa e caracterizada por fenómenos de permanente e célere alteração. Verificou-se assim a sucessão de várias intervenções legislativas. Aqui se manifesta também o embaraço do intérprete chamado a descortinar, a interpretar e a conformar

5 Cfr. Anna Rosa FAVRetTo, Diritto e Famiglie in Itália: una Convivenza Problematica, in Come il Diritto Trata le Famiglie, a cura di Guido Maggioni, Collana de Centro Universitario di Ricerche e Studi Sulle Famiglie, QuatroVenti, Urbino, 1996, p. 210.

${ }^{6}$ Cfr. Francesco D'Agostino, Linee de una Filosofia della Famiglia nella Prospettiva della Filosofia des Diritto, Milano, Giuffrè Editore, 1991, p. 53. Aliás, esse fenómeno de substituição nunca poderia verifica-se, pois que, segundo o mesmo autor, a experiência familiar é constitutiva do bumanum. 
segundo a ideia de Direito a dinâmica dos dados institucionais face aos movimentos da realidade social 7 .

A sociedade hodierna não aceita facilmente aquelas restrições à autonomia tradicionalmente implicadas pela celebração do casamento. A adopção do sistema de divórcio pura constatação da ruptura do casamento - o direito de livremente sair do casamento de que cada um dos cônjuges é titular - realça claramente a tentativa de protecção da autonomia no seio da relação conjugal.

Entre os sistemas de divórcio-sanção, divórcio-remédio e divórcio pura constatação da ruptura do casamento, o legislador optou claramente pelo último. Eliminou-se, consequentemente, o ilícito culposo como fundamento do divórcio sem o consentimento do outro cônjuge e alargaram-se os fundamentos objectivos da ruptura conjugal relevando qualquer causa que demonstre a ruptura definitiva do casamento (art. 1781. ${ }^{\circ}$, al $d$ ), do Cód. Civil).

Privilegiou-se o mútuo acordo. O divórcio por mútuo consentimento é da competência do tribunal no caso de os cônjuges não alcançarem os acordos complementares do divórcio respeitantes à atribuição da casa de morada da família, aos alimentos entre si e ao exercício das responsabilidades parentais (art. $1775 .^{\circ}$ n. ${ }^{\circ} 1$, do Cód. Civil). Daqui decorre que a celebração destes acordos traduz apenas e tão somente um requisito de competência da conservatória do registo civil. O divórcio por mútuo consentimento poderá também ser decretado pelo tribunal na hipótese de algum dos acordos

7 Cfr. JOÃO BAPTISTA MACHADO, Introdução ao Direito e ao Discurso Legitimador, Almedina, Coimbra, 1987, p. 120.

Pode dizer-se que a história recente do direito da família é a história do modo como o ordenamento jurídico tem vindo a regular a família "not as an organic unit bound by ties of relationship, but as a loose association of separate individuals". Cfr. ELIZABETH SCOTT, Rehabilitating Liberalism in Modern Divorce Law, in 1994 Utah Law Review 687, 1994, p. 687.

O direito da família contempla actualmente relações familiares e parafamiliares cuja composição flexível decorre de critérios funcionais. A prevalência da função sobre a forma não deixa de colocar, contudo, algumas questões de política legislativa. 
apresentados pelos interessados não ser homologado ou quando se obtenha acordo no âmbito de processo de divórcio sem consentimento do outro cônjuge.

Com base na alteração do próprio sistema de divórcio, e também da concepção do casamento, o divórcio passou a ser causa de cessação das relações familiares de afinidade (art. 1585. ${ }^{\circ}$ do Cód. Civil) $^{8}$. Do mesmo modo, nenhum dos cônjuges pode agora na partilha receber mais do que perceberia se o casamento tivesse sido celebrado segundo o regime da comunhão de adquiridos, ainda que o regime convencionado seja o da comunhão geral, ou um outro regime misto mais próximo da comunhão geral do que da comunhão de adquiridos (art. 1790. ${ }^{\circ}$ do Cód. Civil)9.

A transição para o sistema de divórcio pura constatação da ruptura do casamento implicou uma mudança de perspectiva na regulamentação das consequências da crise conjugal, desvanecendo-se também eventuais juízos de responsabilidade de cada um dos cônjuges por essa mesma ruptura. Acresce que a cada sistema de divórcio corresponde uma determinada concepção do casamento no respectivo ordenamento jurídico.

No debate sobre a potencial tensão entre comunhão, autonomia e igualdade, tende a eleger-se um desses valores em detrimento dos restantes. Alguns, exaltando a dimensão da comunhão do casamento, negligenciam a igualdade e a autonomia ${ }^{10}$. Por seu turno, os que

8 Trata-se do recurso ao argumento a contrario. Na verdade, precisamente porque o legislador, no art. $1585 .^{\circ}$ do Cód. Civil, ligou a consequência jurídica (persistência das relações de afinidade) à previsão (dissolução do casamento por morte de um dos cônjuges), aquela não vale para a dissolução do casamento por divórcio. A subsistência do vínculo de afinidade foi querida claramente pelo legislador justamente para a dissolução do casamento por morte de um dos cônjuges.

9 A partilha continua a seguir o regime convencionado no caso de dissolução por morte.

10 Cfr. LYNN D. WARDLE, No-Fault Divorce and the Divorce Conundrum, in 1991 Brigham Young University Law Review 79, p. 121-124. 
vêem no casamento um mero contrato, relevando a igualdade e a autonomia, ignoram o vector da comunhão ${ }^{11}$.

$O$ entendimento do casamento enquanto comunhão de vida baseada na liberdade e na igualdade consubstancia o fundamento normativo da regra da partilha do património comum do casal em partes iguais após o divórcio (art. $1730 .^{\circ}$ do Cód. Civil). Esta regra visa também, de algum modo, mitigar aquela vulnerabilidade inevitável que é intrínseca às relações duradouras de confiança e de cooperação ${ }^{12}$. Trata-se outrossim de valorizar as contribuições pessoais e o trabalho não remunerado para os encargos da vida familiar ${ }^{13}$. O casamento pós-moderno é considerado como uma associação económica inspirada num princípio de partilha. Os cônjuges, em conjunto, tomam decisões sobre o investimento na carreira profissional e no capital humano de cada um deles, resoluções estas que, em último termo, beneficiam a família conjugal.

11 Cfr. LENORE J. WeITZMAn, The Marriage Contract: Spouses, Lovers, and the $L a w$, p. 225-54, Free Press, New York, 1981, (chamando a atenção para a promoção de relações de igualdade ao preconizar a substituição do casamento por intimate contracts); MARTHA M. ERTMAN, Marriage as a Trade: Bridging the Private/Public Distinction, in 36 Harvard Civil Rights-Civil Liberties Law Review 79, 2001, p. 79-85 (propondo a redução da desigualdade nos modelos tradicionais do direito da família mediante a sua transformação em business structures); MARJORIE MAGUIRE SHULTZ, Contractual Ordering of Marriage: A New Model for State Policy, in 70 California Law Review 207, 1982, p. 250-253 (apontando a centralidade do individualismo enquanto base do respeito pela autonomia privada no âmbito matrimonial); CAROLYYN J. FRANTZ/HANOCH DAGAN, Properties of Marriage, in 104 Columbia Law Review 75, 2004, p. 77-79.

12 Cfr. CARolyyn J. Frantz/Hanoch Dagan, Properties of Marriage, in 104 Columbia Law Review 75, 2004, p. 95-96.

13 Cfr. Francisco manuel Pereira Coelho/Guilherme De Oliveira, Curso de Direito da Família, Volume I, Coimbra Editora, Coimbra, 2008, p. 506 e ss.; MARIA JOÃO VAZ TOMÉ, O direito à pensão de reforma enquanto bem comum do casal, Coimbra Editora, Coimbra, 1997, p. 153 e ss.; MARY ANN GLENDON, The New Family and the New Property, Butterworth's, London, 1981, p. 63; MARTHA ALBERT- SON FINEMAN, Our Sacred Institution: The Ideal of the Family in American Law and Society, in 1993 Utah Law Review 387, p. 397; JANA B. SINGER, Divorce Reform and Gender Justice, in 67 North Carolina Law Review 1103, 1989, p. 1114. 
Desta concepção do casamento decorre, naturalmente, a aceitação do divórcio e a gestão responsabilizada das suas consequências. $\mathrm{O}$ princípio da liberdade de escolha dos cônjuges postula que ninguém deve permanecer casado contra sua vontade. A invocação da ruptura definitiva da vida em comum é fundamento suficiente para que o divórcio seja decretado. A metamorfose do sistema de divórcio em vista da auto-realização insere-se num ethos de autonomia pessoal no domínio das relações de intimidade. "A estabilidade da família está nas mãos dos cônjuges”, não podendo o Direito garanti-la contra a vontade dos interessados. Na verdade, o significado jurídico do casamento mudou, especialmente neste século. O reconhecimento progressivo da individualidade humana resultou numa evolução do matrimónio de um estatuto virtualmente imutável para um facilmente dissolúvel ${ }^{14}$.

$O$ casamento encontra-se fundado na igualdade enquanto pressuposto da liberdade. A acentuação da liberdade individual não é incompatível, quando adequadamente dimensionada, com a realização de uma igualdade efectiva na hodierna sociedade dinâmica.

O legislador adoptou um modelo individualístico-associativo, baseado na plena igualdade dos cônjuges, um modelo que valoriza essencialmente a dimensão afectiva enquanto agregadora e legitimadora da sociedade conjugal, enquanto lugar de manifestação e de desenvolvimento da personalidade de cada um dos cônjuges e, consequentemente, mais exposto à eclosão de conflitos ${ }^{15}$.

Procuram-se equilíbrios normativos, a conciliação entre a liberdade e a igualdade, a responsabilidade e a solidariedade. A tarefa do legislador é essencialmente delicada, pois que árdua é a tentativa de compor num equilíbrio harmonioso e estável a pluralidade

\footnotetext{
${ }^{14}$ Preconizando-se uma espécie de individualismo solitário.

15 Cfr. MARIA JOÃO VAZ TOMÉ, O direito à pensão de reforma (por velhice) no divórcio - algumas considerações, Tribunal de Contas, Seminário "Direito da Segurança Social", Lisboa, 2000, p. 150 e ss.
} 
dos interesses em jogo. Está em causa sobretudo a articulação das consequências do divórcio, de modo a assegurar, tanto quanto possível, o máximo de protecção dos sujeitos considerados merecedores de especial tutela, com o mínimo de sacrifício daquela liberdade. Compete-lhe também conformar aquela solidariedade patrimonial que encontra na comunhão conjugal a sua mais forte afirmação, regular os efeitos da interdependência e da osmose das dimensões económicas e não económicas da vida de cada um dos cônjuges implicada pelo modus vivendi em comunhão ${ }^{16}$.

Tem-se em vista o equilíbrio entre a liberdade e a tutela do cônjuge economicamente mais vulnerável, entre a atenuação efectiva dos reflexos, também económicos, do vínculo conjugal e a protecção do cônjuge economicamente mais fraco. Em causa estão pois os princípios da igualdade dos cônjuges e da protecção do cônjuge economicamente mais fraco ou mais vulnerável. O legislador, por intermédio de normas de ordem pública de carácter essencialmente económico, tutela o cônjuge patrimonialmente mais frágil ${ }^{17}$.

Da celebração do casamento resulta uma comunhão fundada na igualdade, devendo os custos e os benefícios ser partilhados, em partes iguais, em qualquer fase da vida da família matrimonial. Impõe-se a consagração de mecanismos idóneos para realizar o princípio da paridade entre cônjuges. $\mathrm{Na}$ dissolução do casamento, surge a exigência de redistribuir equitativamente os sacrifícios e os benefícios, de compensar os investimentos em capital humano e de garantir uma partilha equilibrada da riqueza. O princípio da igualdade dos cônjuges, que rege toda a vida matrimonial, postula que,

16 Cfr. BenOIT MOORE, Quelle Famille Pour Le XXIe Siécle?: Perspectives Quebecoises, in 20 Canadian Journal of Family Law 57, 2003, p. 92-93.

17 O direito da família foi sempre um domínio de eleição da ordem pública. Cfr. ChristiANNE DUBREUIL, BRIGITTE LEFEBVRE, L'ordre public et les rapports patrimoniaux dans les relations de couple, in 40 Les Cahiers de Droit 345, 1999, p. 346. 
também na sua dissolução, os cônjuges tenham direitos iguais, não sendo admissível o enriquecimento de um e o prejuízo de outro.

Vigora o princípio da igualdade de direitos e de deveres entre cônjuges (art. 1671. ${ }^{\circ}$, n. $^{\circ} 1$, do Cód. Civil). A afectividade encontra-se no centro da relação conjugal enquanto plena comunhão de vida, cooperação e auxílio mútuo na educação dos filhos, quando os houver. A natureza do casamento como que sofreu uma metamorfose em resultado de um processo de sentimentalização e de individualização, relegando-se para segundo plano as dimensões contratual, económica e patrimonial da conjugalidade.

Todavia, quase quatro décadas volvidas sobre a entrada em vigor da Reforma do Código Civil de 1977, é ainda evidente que à igualdade de direitos e de deveres dos cônjuges legalmente consagrada não corresponde a igualdade de facto ${ }^{18}$.

Verifica-se, na verdade, uma desigualdade significativa de contributos para a vida familiar, apesar de a realidade portuguesa estar longe do modelo do "casamento da dona de casa". Não obstante a equiparação do trabalho doméstico ao trabalho remunerado, enquanto modalidades de cumprimento do dever de contribuição para os encargos da vida familiar (art. $1676 .^{\circ}$, n. $^{\circ} 1$, do Cód. Civil), esse trabalho realizado na família não é juridicamente valorizado de forma adequada. O reconhecimento do valor do cuidado dos dependentes e da gestão doméstica é recente. Por isso, a lei estabelece a possibilidade de atribuição de créditos de compensação sempre que se verificar uma assimetria entre os cônjuges nas contribuições para os encargos da vida familiar. A necessidade de conciliação entre a

18 Cfr. MARIA JOÃo VAZ TOMÉ, "A esquecida conexão patrimonial entre o direito da família e o direito da segurança social", Comemorações dos 35 Anos do Código Civil e dos 25 Anos da Reforma de 1977, Volume I, Direito da Família e das Sucessões, Faculdade de Direito da Universidade de Coimbra, Coimbra Editora, Coimbra, 2004, p. 524 e ss. 
família e a vida profissional conduz a mulher, muito frequentemente, a dar primazia à primeira em detrimento da segunda.

Considerando a importância dos contributos para a vida conjugal e familiar do cuidado dos filhos e do trabalho despendido no lar, estabelece-se que poderá haver lugar a um crédito de compensação em situação de desigualdade manifesta dessas contribuições (art. 1676. ${ }^{\circ}$, n. $^{\circ}$ 2, do Cód. Civil) ${ }^{19}$. Procura evitar-se o agravamento de

19 Cfr. MARIA JOÃO VAZ TOMÉ, Algumas reflexões sobre a obrigação de compensação e a obrigação de alimentos entre ex-cônjuges, in Estudos em Homenagem ao Professor Doutor Heinrich Ewald Hörster, Almedina, Coimbra, 2012, p. 425 e ss. O legislador estabelece um regime patrimonial primário, de natureza imperativa, fundado nos princípios da igualdade e da solidariedade. Se muitas das normas que o compõem se aplicam na vigência da relação conjugal, outras apenas produzem efeitos após a sua dissolução, como é o caso da obrigação de compen- sação. Não é tarefa fácil estabelecer critérios suficientemente flexíveis para levar em linha de conta a diversidade de relações matrimoniais. A organização da família actual, nuclear ou não, é muito variável. O casamento do "ganha-pão/dona de casa" tende a ser raro, pois a maior parte das famílias necessita de dois rendimentos pecuniários para subsistir. Contudo, a distribuição da responsabilidade pela gestão da vida familiar não acompanhou essa evolução. Cfr. JENNIFER R. JOHNSON, Preferred by Law: The Disappearance of the Traditional Family and Law's Refusal to Let It Go, in 25 Women's Rights Law Reporter 125, 2004, p. 129. Por via de regra, a contribuição do cônjuge mulher para os encargos da vida familiar ultrapassa consideravelmente o que lhe era exigível, sendo esta conduta considerada "eficiente" na vigência da relação matrimonial.

A gestão da vida familiar, na esmagadora maioria dos casos exercida predominantemente pelo cônjuge mulher, que permite o estatuto de trabalhador ideal ao cônjuge marido, foi considerada como digna da tutela do ordenamento jurídico. Na verdade, essa gestão tem um impacto adverso na capacidade aquisitiva do cônjuge que a ela se dedica, independentemente de se tratar de abandono temporário da carreira profissional, de ocupação profissional a tempo parcial ou de trabalho a tempo inteiro. Realiza, muito frequentemente, sacrifícios profissionais para dedicar mais tempo à educação dos filhos e ao cuidado do lar. O cônjuge mulher que concilia desta forma a vida profissional com a vida familiar depara com o fenómeno denominado como "mommy track" (abrandamento da evolução na carreira, menores oportunidades de progressão e de aumento salarial e, consequentemente, menor tutela pensionística). $O$ conflito entre a responsabilidade profissional e a responsabilidade familiar tende, aliás, a intensificar-se na medida em que se generaliza o modelo do ganha-pão universal e em que aumenta o número de famílias monoparentais. Há inegavelmente custos de mercado associados à gestão da vida familiar e ao cuidado dos dependentes. Cfr. MARIA JOÃO VAZ TOMÉ, Considerações sobre alguns efeitos patrimoniais do divórcio na Lei $n .^{\circ}$ 61/2008, de 31 de Outubro: (in)adequação às realidades familiares do século XXI, in E foram felizes para sempre...?, Uma Análise Crítica do Novo Regime Jurídico do Divórcio, Coordenação por Maria Clara Sottomayor/Maria Teresa Féria de Almeida, Walter Kluwer/ Coimbra Editora, Coimbra, 2010, p. 182 e ss.; CYNTHIA 
situações de desigualdade e assimetria entre cônjuges, protegendo-se a parte mais fraca.

O sistema de tutela anterior à reforma de 2008 apresentava, efectivamente, lacunas. Todavia, o cônjuge que na vigência do casamento sacrificou as suas aspirações profissionais para se dedicar à

LEE STARnes, Mothers as Suckers: Pity, Partnership, and Divorce Discourse, in 90 Iowa Law Review 1513, 2005, p. 1516. Não se trata, todavia, da consideração das mães como vítimas de acasos ou de decisões menos felizes (desinvestimento no mercado de trabalho), mas antes como prestadoras de um bem necessário (cuidado familiar). Contudo, mesmo beneficiando o cônjuge marido e os filhos desta conduta na vigência da sociedade conjugal, é o cônjuge mulher que, no divórcio, arca com os custos inerentes a estas decisões. Por via de regra, na dissolução do casamento por divórcio, o cônjuge mulher suporta um declínio significativo no seu nível de vida. Mesmo o cônjuge mulher que exerce uma actividade remunerada experimenta essa perda económica. Apesar de ter permanecido no mercado de trabalho, sofre a redução da sua capacidade aquisitiva como efeito do seu maior investimento, na vigência do casamento, na gestão da vida familiar. No divórcio, o seu estatuto de trabalhadora remunerada, esbatendo a situação de necessidade, é susceptível de não lhe permitir ser credora de alimentos. Assim, ficaria claramente por compensar a perda de capacidade de aquisição por si sofrida. Não se trata, todavia, da consideração das mães como vítimas de acasos ou de decisões menos felizes (desinvestimento no mercado de trabalho), mas antes como prestadoras de um bem necessário (cui- dado familiar). Cfr. TONYA L. BRITO, Spousal Support Takes on the Mommy Track: Why the ALI Proposal Is Good for Working Mothers, in 8 Duke Journal of Gender Law E Policy 151, 2001, p. 151; PENELOPE EILEEN BRYAN, Vacant Promises?: The ALI Principles of the Law of Family Dissolution and the Post-Divorce Financial Circumstances of Women, in 8 Duke Journal of Gender Law E Policy 167, 2001, p. 172. À obrigação de compensação parece estar subjacente a ideia de partilha equitativa de determinadas perdas. As alterações sofridas pela capacidade aquisitiva do cônjuge mulher, na vigência do casamento, são merecedoras da tutela do ordenamento jurídico e, por isso, de compensação no divórcio. Cfr. TONYA L. BRITO, Spousal Support Takes on the Mommy Track: Why the ALI Proposal Is Good for Working Mothers, in 8 Duke Journal of Gender Law \& Policy 151, 2001, p. 155-156. A direcção da família pertence a ambos os cônjuges, que devem acordar sobre a orientação da vida em comum tendo em conta o bem da família e os interesses de um e outro (art. 1671. ${ }^{\circ},{ }^{\circ} .^{\circ} 1$, do Cód. Civil). Cada um dos cônjuges toma decisões inspiradas mais no bem-estar da família do que no seu interesse individual. A gestão da vida familiar compromete, em geral, a participação do cônjuge mulher no mercado de trabalho e, por isso, aumenta o seu risco diferencial no divórcio. Por isso, o legislador não confina a prestação compensatória a casamentos de determinada duração. Na verdade, também num casamento de curta duração, o cônjuge mulher poderá sofrer um risco diferencial significativo no divórcio. Se abandona o mercado de trabalho, a sua capacidade aquisitiva fica, em regra, definitivamente comprometida. Cfr. PENElOPE EILEEN BRYAN, Vacant Promises?: The ALI Principles of the Law of Family Dissolution and the Post-Divorce Financial Circumstances of Women, in 8 Duke Journal of Gender Law \& Policy 167, 2001, p. 173, 176. Em qualquer caso, com o divórcio termina o período de gestão do lar e de assistência relevante para o efeito da atribuição do 
gestão doméstica e ao cuidado dos filhos não é ainda adequadamente protegido. Por outro lado, o legislador não levou em devida linha de conta a subsistência das exigências de organização da vida da família para além da dissolução do casamento.

\section{A obrigação de alimentos entre ex-cônjuges}

\subsection{Fundamento}

Questão essencial é a do fundamento da obrigação de alimentos entre ex-cônjuges no novo direito da família, num sistema de divórcio de pura constatação da ruptura do casamento (art. $1773 .^{\circ}$ do Cód. Civil), de igualdade dos géneros (art. 1671. ${ }^{\circ}$, n. $^{\circ} 1$, do Cód. Civil) e de partilha em partes iguais do património comum do casal (art. $1730 .^{\circ}$ do Cód. Civil) ${ }^{20}$.

As alterações sofridas pelo regime jurídico da obrigação de alimentos decorrem, em grande medida, da transição para o sistema do divórcio pura constatação da ruptura e correspondem à opção legislativa de permitir a livre saída do casamento. A possibilidade de sair não deve ser apenas formal, devendo também reflectir-se no direito patrimonial do divórcio. Não apenas e tão-somente a relação conjugal, mas também as consequências patrimoniais por si implica-

\footnotetext{
direito à compensação, não se reconhecendo a perda diferencial na capacidade aquisitiva que o cônjuge mulher experimenta após a dissolução do casamento em virtude do exercício das respectivas responsabilidades parentais. A figura primária de referência, após um casamento de curta duração, a quem é confiada a guarda de filhos de tenra idade, é susceptível de sofrer uma perda que continua a não ser devida e adequadamente tutelada.

O fundamento da obrigação prevista no art. $1676 .^{\circ}$, n. ${ }^{\circ}$ 2, do Cód. Civil, não se encontra numa ideia de titularidade ou de necessidade e independe da culpa pela ruptura da sociedade conjugal. Em causa está, essencialmente, a perda de capacidade aquisitiva decorrente de uma contribuição para os encargos da vida familiar consideravelmente superior às possibilidades de quem a realiza.

20 Cfr. CAROL Rogerson, The Canadian Law of Spousal Support, 38 Family Law Quarterly 69, 2004, p. 71.
} 
das devem terminar no divórcio. Por conseguinte, aquelas mesmas razões que conduzem à adopção daquele sistema de divórcio levam à preconização de uma nova obrigação de alimentos.

Em todos os ordenamentos jurídicos em que se contempla a possibilidade de atribuição de um direito a alimentos pós-divórcio, a ideia central gira em torno do facto de, uma vez dissolvido o casamento e, consequentemente, desaparecidos os deveres recíprocos de cooperação e de assistência que vinculavam os cônjuges como efeito do matrimónio, um deles poder vir a encontrar-se em situação de necessidade. A questão essencial suscitada pela atribuição de um direito a alimentos consiste em saber se, na realidade, esse direito cumpre os requisitos próprios de toda e qualquer direito a alimentos, ou seja, até que ponto uma (não)relação derivada da dissolução do casamento se afigura idónea para dar origem a uma verdadeira relação alimentar entre as partes. Trata-se de saber se a qualidade de ex-cônjuge, se o status de divorciado, atribui àquele que se encontra em necessidade o direito de exigir do outro alimentos ou, pelo contrário, se se terá forçado a instituição alimentar conferindo-se-lhe uma função que desvirtua a sua própria natureza.

Poderia dizer-se que a diversidade entre as várias obrigações alimentares lato sensu não deve ser exacerbada ao ponto de eliminar aquele denominador comum que se traduz na solidariedade familiar. Esta solidariedade consubstancia o fundamento da atribuição ex lege da obrigação de alimentos. Consequentemente, o facto de a mesma solidariedade ser susceptível de assumir maior ou menor intensidade, conforme circunstâncias pré-ordenadas pela lei e inspiradas em exigências essenciais de equidade, explica como entre os diversos institutos, assim como no âmbito de cada um deles, quer os critérios de atribuição, quer aqueles que lhe determinam o montante possam variar em concreto $^{21}$.

21 Cfr. Gabriella Autorino Stanzione, Diritto de Famiglia, Torino, G. Giappichelli Editore, 1997, p. 181. 
Ao regular o divórcio, o legislador muito dificilmente poderia esquecer o passado comum dos cônjuges e os futuros separados dos ex-cônjuges.

A obrigação de alimentos como efeito do divórcio foi sempre objecto de controvérsia, pois não se encontrou um fundamento consensualmente idóneo para obrigar um dos ex-cônjuges - em lugar dos membros da respectiva família ou da sociedade - a alimentar o outro ${ }^{22}$. Verifica-se a ausência de consensus omnium sobre o fundamento desta obrigação.

Em minha opinião, o fundamento último, ético e jurídico, da obrigação de alimentos entre ex-cônjuges encontra-se num princípio de solidariedade pós-conjugal. Não se pode, com efeito, tratar os ex-cônjuges como se nunca houvessem sido casados. É que o divórcio não pode apagar o passado nem obstar ao desenvolvimento actual de determinadas consequências do matrimónio. Trata-se como que de uma eficácia póstuma do vínculo matrimonial, de um efeito ultra-activo do casamento.

\subsection{Natureza}

Trata-se agora de se saber se obrigação de alimentos entre ex-cônjuges se reveste de natureza alimentar, indemnizatória ou compensatória.

Tal como na lei do casamento de 25 de Dezembro de 1910 e na lei do divórcio de 4 de Novembro de 1910, a culpa não releva, por via de regra, no âmbito da obrigação de alimentos como efeito do divórcio. A natureza alimentar da obrigação em apreço é clara. Não sendo determinado pelos danos sofridos pelo alimentando, o montante da prestação alimentar é fundamentalmente fixado aten-

22 Cfr. JENNIFER L. MCCOY, Comment: Spousal Support Disorder: An Overview of Problems in Current Alimony Law, in 33 Florida State University Law Review 501, 2005, p. 506; IRA MARK ELLMAN, The Theory of Alimony, in 77 California Law Review 1, 1989, p. 5. 
dendo às necessidades do credor e aos recursos do devedor, pois que os alimentos devem ser prestados na proporção da necessidade do alimentando e das condições económicas do alimentante (art. $2004 .^{\circ}$ do Cód. Civil). Acresce que, de acordo com o art. 2008. ${ }^{\circ}$ do Cód. Civil, o direito a alimentos é indisponível e impenhorável, pois está em causa a aplicação dos alimentos às necessidades do alimentando. Por isso mesmo, é também um direito irrenunciável e incompensável.

O carácter essencialmente alimentar deste direito é reforçado pela possibilidade de alteração dos alimentos fixados nos termos do art. 2012. ${ }^{\circ}$ do Cód. Civil. Leve-se ainda em linha de conta que o direito a alimentos cessa se terminar a necessidade do seu titular, se o obrigado não tiver recursos e, também, com a morte do credor ou do devedor.

Elimina-se a apreciação da culpa na ruptura da sociedade conjugal, porque se quer reduzir a questão ao seu núcleo essencial: a assistência de quem precisa por quem tem possibilidades. Prevê-se, todavia, uma cláusula de equidade negativa ("razões manifestas de equidade"), na medida em que, em casos excepcionais, o direito de alimentos pode ser negado ao ex-cônjuge necessitado por ser chocante onerar o outro com a obrigação correspondente (art. 2016. , n. ${ }^{\circ}$ 3, do Cód. Civil). A lei não define "razões manifestas de equidade", tendo o legislador recorrido à técnica legislativa da cláusula geral e dos conceitos indeterminados. Trata-se da necessidade de permeabilidade e de adaptação da ordem jurídica aos seus fundamentos ético-sociais ${ }^{23}$.

$23 \mathrm{O}$ recurso às técnicas legislativas dos conceitos indeterminados e das cláusulas gerais justifica-se para permitir a adaptação da norma à complexidade da matéria a regular, às particularidades do caso ou à mudança das situações, ou para facultar uma espécie de osmose entre as máximas ético-sociais e o Direito, ou para permitir levar em conta os usos do tráfico ou uma individualização da solução. Cfr. JOÃO BAPTISTA MACHADO, Introdução ao Direito e ao Discurso Legitimador, Almedina, Coimbra, 1987, p. 114. 
A culpa continua, por isso, através da implementação valorativa daqueles conceitos indeterminados, a desempenhar algum papel, ainda que nem sempre visível, no âmbito da obrigação de alimentos. A ideia de culpa ressurge assim tímida e palidamente, pois que o legislador se deparou com a dificuldade da sua total e absoluta erradicação da regulamentação dos efeitos do divórcio.

A obrigação de alimentos independe da culpa do alimentando na ruptura da sociedade conjugal. De acordo com a natureza alimentar da obrigação em apreço, a culpa assume um papel residual e, por conseguinte, a responsabilidade pela desagregação da vida conjugal é susceptível de produzir efeitos no an - e não no quantum - do direito correspondente (art. 2016. ${ }^{\circ},{ }^{\circ}{ }^{\circ} 3$, do Cód. Civil). Deste modo, com base em "razões manifestas de equidade", o ex-cônjuge necessitado não terá sequer direito a alimentos que lhe consintam o mínimo vital. O legislador não resolveu pois de forma plena o conflito entre o sistema de divórcio pura constatação da ruptura e a (des)consideração da culpa.

Penso que a natureza alimentar da obrigação em apreço resulta da lei. Quaisquer que sejam as circunstâncias dos cônjuges referenciadas no art. 2016..$^{\circ}$ A, n. ${ }^{\circ}$ 1, do Cód. Civil (a duração do casamento, a colaboração prestada à economia do casal, a idade e estado de saúde dos cônjuges, as suas qualificações profissionais e possibilidades de emprego, o tempo que terão de dedicar, eventualmente, à criação de filhos comuns, os seus rendimentos e proventos, um novo casamento ou união de facto e, de modo geral, todas as circunstâncias que influam sobre as necessidades do cônjuge que recebe os alimentos e as possibilidades do que os presta), a obrigação de alimentos apenas existe quando um dos cônjuges não tenha meios, e não possa tê-los por razões objectivas, para prover à sua subsistência. A falta de meios é o único pressuposto condicionante do reconhecimento do direito a alimentos. A obrigação de alimentos não reveste pois natureza indemnizatória. Poderia, 
todavia, reconhecer-se-lhe também natureza compensatória, dado que, na fixação do respectivo montante, importa levar em conta o critério da colaboração prestada pelo credor à economia do casal (art. 2016. ${ }^{\circ}$ A, n. ${ }^{\circ}$ 1, do Cód. Civil).

A consideração da colaboração prestada à economia do casal em sede de obrigação de alimentos não duplica, necessariamente, a tutela prevista já para essa mesma colaboração em sede de obrigação de compensação (art. 1676. ${ }^{\circ}$, n. ${ }^{\circ}$ 2, do Cód. Civil). De um lado, pode dizer-se que, em último recurso, não é a colaboração, em si mesma, enquanto causa da perda da capacidade aquisitiva, que releva em sede alimentar, mas antes as sequelas alimentares, a situação de necessidade a que poderá ter votado o cônjuge que a prestou e, de outro lado, essa colaboração poderá, no caso concreto, não cumprir, por não ser excessiva, os requisitos legalmente previstos para fundar o direito à compensação.

\subsection{Modelo alimentar}

O credor típico de alimentos é o cônjuge mulher que, no casamento, conforma a sua conduta a um modelo patriarcal: a mulher que altruisticamente devota décadas da sua vida ao cuidado do marido, dos filhos, muito frequentemente também de outros parentes ou afins, e à gestão doméstica e que, ao tempo do divórcio, tem filhos adultos, aptidões profissionais reduzidas e uma parca capacidade aquisitiva. Por seu turno, o cônjuge marido investe na sua carreira profissional e deixa o casamento com uma capacidade aquisitiva que não é entretanto negativamente afectada.

Porém, o modelo alimentar tradicional - a satisfação, após a dissolução por divórcio de um casamento de longa duração, das necessidades do cônjuge que, na vigência da relação conjugal, assumiu o papel de dona de casa e/ou mãe - já não encontra ressonância na maioria das relações matrimoniais. Os padrões do mercado de trabalho e da família sofreram grandes metamorfoses nas últimas 
quatro décadas. Em lugar do modelo do "casamento dona de casa/ ganha-pão" prevalece o modelo do "ganha-pão universal". Ambos os cônjuges têm, por via de regra, uma carreira profissional ${ }^{24}$. As investigações empíricas demonstram, todavia, que é o cônjuge mulher que realiza a maior parte do trabalho doméstico e de assistência aos dependentes 25 .

24 Cfr. TONYA L. BRITO, Spousal Support Takes on the Mommy Track: Why the ALI Proposal Is Good for Working Mothers, in 8 Duke Journal of Gender Law E Policy 151, 2001, p. 153-154.

25 Ignora-se, muito frequentemente, que o estado de dependência é inerente à condição humana, que é naturalmente desenvolvimental. Nesta perspectiva, a dependência desenvolvimental surge como universal e inevitável. Qualquer pessoa é dependente enquanto criança e poderá tornar-se dependente à medida do envelhecimento, enquanto doente ou padecendo de qualquer tipo de invalidez ou incapacidade. Por seu turno, cuidar de um dependente inevitável gera uma diferente forma de dependência no indivíduo que presta esse cuidado: uma dependência derivada ou consequencial. É derivada ou consequencial porquanto aquele que cuida dos outros depende, ele próprio, de recursos que lhe permitam prestar essa assistência. Esta modalidade de dependência é, muito frequentemente, descurada pelo ordenamento jurídico. Longe de acondicionar a função de cuidado, o mercado de trabalho parte de pressupostos que traduzem a incompatibilidade do trabalho de assistência familiar com as normas do trabalho remunerado. Para aqueles que assumem a responsabilidade dos dependentes, as normas e expectativas do local de trabalho competem com as da dependência e, nesta medida, a prestação de assistência interfere ou preclude até o desenvolvimento de trabalho remunerado. Cfr. MARTHA AlBertson FinemAn, Fatherhood, Feminism and Family Law, 32 McGeorge Law Review 1030, 2001, p. 1032-1033. Os dependentes derivados, como resultado da necessidade de cuidado apresentada pela dependência natural ou desenvolvimental, precisam, eles próprios, de recursos económicos. Carecem de apoio institucional, assim como de alguns ajustamentos estruturais que lhes permitam realizar a prestação de cuidado. A assistência à dependência é exigente, pois que as normas de sacrifício e de altruísmo são claras e austeras. A dependência derivada ou consequencial, diferentemente da dependência natural ou desenvolvimental, não é uma experiência universal, pois nem todos os membros da sociedade desempenham esse papel. Cfr. MARTHA ALBERTSON FINEMAN, Masking Dependency: The Political Role of Family Rhetoric, 81 Virginia Law Review 2181, 1995, p. 2200. Pode afirmar-se que, actualmente, a dependência desenvolvimental ou inevitável, assim como a dependência derivada ou consequencial, por ela implicada, são, em grande medida, consideradas do foro privado e por isso atribuídas quase exclusivamente à responsabilidade da família. Assim, a instituição da família liberta o mercado para se organizar sem levar em linha de conta ou acomodar essas dependências. O Estado actua subsidiariamente como instituição que prevê como que uma assistência mínima para o caso de a família não cumprir a sua função de cuidado pelos dependentes. Cada família é idealmente considerada responsável pela dependência dos seus membros. Apenas a ausência de satisfação adequada 
Em virtude de poucos postos de trabalho tradicionais permitirem a autonomia e a flexibilidade requeridas por uma conciliação efectiva entre a vida profissional e a vida familiar, as soluções encontradas

das necessidades dos seus membros é susceptível de transferir a família da esfera privada para a esfera pública, onde é então regulada e disciplinada.

A conferência da responsabilidade pela dependência inevitável ou desenvolvimental desde logo à família e, em segundo lugar, dentro da família, muito frequentemente ao cônjuge mulher, não se afigura justa. A satisfação das necessidades dos dependentes tem, para aquele que presta esse cuidado, consequências significativas. Um dos resultados da privatização da dependência desenvolvimental ou inevitável é de algum modo a frustração da aspiração à igualdade dos géneros e dos cônjuges. Não se assegura assim o interesse do Estado na justiça e na igualdade nas relações familiares.

De acordo com a privatização da dependência, a família é também considerada a fonte dos recursos económicos necessários para a prestação de cuidado aos dependentes pois que, numa perspectiva histórica, competia ao "ganha-pão" fornecer esses meios. Cfr. MARTHA ALBERTSOn FInEMAn, The Autonomy Myth, A Theory of Dependency, The New Press, New York, London, 2004, p. 44 e ss. Espera-se que o dependente derivado ou consequencial encontre os recursos económicos e estruturais de que necessita no seio da própria comunidade familiar. O mercado de trabalho não assume qualquer tipo de responsabilidade, não se envolve. O Estado, por seu lado, conforme o princípio da subsidiariedade, é considerado como o último recurso para a obtenção dos respectivos meios materiais. Negligenciam-se os custos directamente decorrentes da assistência aos dependentes. Esquece-se que a prestação de cuidado é susceptível de dificultar o desenvolvimento de uma carreira profissional, a realização pessoal, de reduzir a compensação económica, de implicar perdas de oportunidades e de originar outros custos associados à prestação assistencial. Mesmo quando participa no mercado de trabalho, a vinculação à esfera pública do responsável pelos dependentes naturais ou inevitáveis é tipicamente mais ténue, pois tem de acomodar devidamente as exigências da esfera privada. Compromete outrossim, por isso mesmo, a aquisição e o conteúdo dos direitos sociais.

A atribuição da dependência à família compreendia-se quando o casamento assentava na estabilidade, em determinada divisão de papéis e os cônjuges se inte- gravam na grande família. Existindo um prestador de assistência e um "ganha-pão", ambos realizando contribuições diferentes mas complementares - proporcionando, respectivamente, o cuidado e os recursos emocionais, por um lado e, por outro, a satisfação das necessidades materiais -, talvez a dependência fosse susceptível de acomodação na família. Cfr. MARTHA ALBERTSON Fineman, Our Sacred Institution: The Ideal of the Family in American Law and Society, 1993 Utah Law Review 387, 1993, p. 400. Na verdade, a teoria da família moderna o desenvolvimento da teoria clássica da família moderna - deve-se, em grande medida, a Gary Becker. A sua perspectiva da especilização de cada um dos cônjuges/progenitores mantém alguma actualidade. Cfr. GARY STANELY BECKER, A Treatise on the Family, Harvard University Press, Cambridge, Massachusetts, London, 1981, p. 14-37 - via na divisão do trabalho de acordo com o género a principal vantagem da realidade familiar, assim como na interdependência entre 
para o conflito entre a vida familiar e a vida profissional contribuem também para o fosso salarial que se verifica entre o cônjuge mulher e mãe e outros participantes no mercado de trabalho ${ }^{26}$.

Note-se que a obrigação de compensação, prevista no art. 1676. ${ }^{\circ}$, n. ${ }^{\circ}$, do Cód. Civil, tem essencialmente por objecto a perda de capacidade aquisitiva e não a necessidade - decorrente de uma contribuição para os encargos da vida familiar consideravelmente superior às possibilidades de quem a realiza e que, em qualquer caso, com o divórcio termina o período de gestão do lar e de assistência relevante para o efeito da atribuição do direito à compensação. É agora o momento de lançar mão da obrigação de alimentos, atendendo às sequelas alimentares deixadas por esse perda de capacidade

marido e mulher ("complementaridade" por oposição a igualdade) um corolário necessário. Cfr. VIVIAN HAMILTON, Mistaking Marriage for Social Policy, 11 Virginia Journal of Social Policy \& the Law 307, 2004, p. 314-315. O casamento pós-moderno é considerado uma associação económica de iguais inspirada num princípio de partilha. Cfr. GARY STANLEY BECKER, A Treatise on the Family, Harvard University Press, Cambridge, Massachusetts, London, 1981, p. 15-37. Os cônjuges, em conjunto, tomam decisões sobre o investimento na carreira profissional e no capital humano de cada um deles, resoluções estas que, em último recurso, beneficiam a família conjugal. Todavia, à medida que a sua capacidade aquisitiva diminui, em virtude da assistência prestada aos dependentes, o cônjuge mulher torna-se mais dependente do cônjuge marido. Esta manifesta-se com parti- cular acuidade na dissolução do casamento por divórcio. Cfr. VIVIAN HAMILTON, Mistaking Marriage for Social Policy, 11 Virginia Journal of Social Policy \& the Law 307, 2004, p. 362-365. Na verdade, a partilha em partes iguais da prestação de cuidado entre os cônjuges não tem, em geral, lugar. Cfr. MARTHA ALBERTSON FINEMAN, The Neutered Mother, the Sexual Family and Other Twentieth Century Tragedies, Routledge, New York, London, 1995, p. 164-166; VIVIAN HAMILTON, Mistaking Marriage for Social Policy, 11 Virginia Journal of Social Policy E the Law 307, 2004, p. 318; MARIA JOÃO VAZ TOMÉ, Algumas considerações sobre a dependência, in Pessoa Humana e Direito, coordenado por Diogo Leite de Campos/Silmara Juny de Abreu Chinellato, Almedina, Coimbra, 2009, p. 295 e ss.

26 A família moderna e pós-moderna enfrenta um desafio difícil. Procura a conciliação entre as exigências do mercado de trabalho com as da gestão familiar. Tanto o bem estar económico como o não económico dependem de um equilíbrio que permita a máxima satisfação e felicidade possível para a família como grupo e, individualmente, para cada um dos seus membros. As escolhas são inevitáveis e devem ser feitas de acordo com os valores e interesses da família. Cfr. AliCiA BROKARS Kelly, Rehabilitating Partnership Marriage as a Theory of Welath Distribution at Divorce: In Recognition of a Shared Life, in 19 Wisconsin Women's Law Journal 141, 2004, p. 185. 
aquisitiva decorrente da prestação de uma contribuição consideravelmente superior às possibilidades do sujeito que a efectuou e que se encontra em necessidade.

Em virtude de o património comum do casal se revelar, na maioria dos casos, exíguo, a obrigação de alimentos como que vem complementar a partilha desse património. Muito frequentemente, esta obrigação reveste-se de maior importância económica para o alimentando do que a própria partilha dos bens comuns do casal.

\subsection{Pressupostos 27}

A determinação do fundamento - princípio da solidariedade pós-conjugal - e da natureza jurídica - alimentar - da obrigação de alimentos entre divorciados afigura-se fundamental para implementar o conceito de necessidade. Este conceito desempenha um papel absolutamente essencial em matéria de alimentos, pois que estes são devidos apenas a quem se encontre em necessidade. Trata-se de estabelecer as circunstâncias que o legislador considerou como de necessidade enquanto pressuposto da obrigação de alimentos e enquanto referente para a quantificação da mesma obrigação. $O$ princípio de solidariedade pós-conjugal permite atender às necessidades de uma vida autónoma e digna, e não apenas às necessidades básicas de sobrevivência ou ao mínimo vital.

A adopção do sistema de divórcio pura constatação da ruptura do casamento conduziu ao acolhimento da necessidade como pressuposto exclusivo da obrigação de alimentos ${ }^{28}$. A relação de

27 Para maiores desenvolvimentos, cfr. MARIA JOÃO VAZ TOMÉ, O direito à pensão de reforma enquanto bem comum do casal, Coimbra Editora, Coimbra, 1997, p. 309 e ss.

28 O sistema de divórcio pura constatação da ruptura do casamento tem em vista remover potenciais obstáculos ao exercício do direito de dissolver o casamento por divórcio. Porém, a obrigação de alimentos pode tornar o divórcio demasiado oneroso, contrariando a ratio subjacente a este sistema de divórcio. Cfr. JENNIFER L. MCCOY, Comment: Spousal Support Disorder: An Overview of Problems in Current Alimony Law, in 33 Florida State University Law Review 501, 2005, p. 507, 521-522; 
consequencialidade entre a necessidade e o direito a alimentos reveste-se de carácter exclusivo no sentido de que para a atribuição deste direito como que nenhuma outra razão releva.

Como que importa agora apenas o carácter objectivo da necessidade. O ex-cônjuge necessitado tem direito a alimentos qualquer que seja a causa que produziu o seu estado de necessidade, desde que tal necessidade não seja susceptível de ser satisfeita mediante um empenhamento diligente.

Encontra-se em necessidade quem não consegue satisfazer adequadamente as necessidades de uma vida autónoma e digna, quer com o seu património, quer com a sua força de trabalho. Se a necessidade do alimentando for susceptível de cessar com o seu trabalho (de acordo com a as suas possibilidades físicas e intelectuais, o seu estado de saúde, etc.), com a abstenção da prática do jogo, da prodigalidade ou de outros vícios e condutas impeditivas do desenvolvimento de uma actividade profissional, não deve então ter direito a alimentos, pois que inexiste uma verdadeira e própria necessidade. Trata-se aqui de uma necessidade voluntariamente criada, independentemente de a conduta do credor criar directa ou tão só indirectamente essa necessidade.

Deve também atender-se aos bens do necessitado, não apenas aos rendimentos produzidos pelos mesmos, assim como à possibilidade de obter dinheiro a crédito, caso lhe seja possível restitui-lo num período de tempo razoável.

No que respeita a bens em princípio improdutivos, há que levar em linha de conta a possibilidade que o alimentando tem ou não de realizar o seu valor.

LARA LENZOTTI KAPAlla, Some Assembly Required: Why States Should not Adopt the ALI'S System of Presumptive Alimony in its Current Form, in 2004 Michigan State Law Review 207, p. 212. 
Por seu turno, na apreciação da sua capacidade de trabalho, relevam a sua formação, as suas aptidões, a sua idade, o seu estado de saúde, assim como o tempo requerido pelo cuidado dos filhos após o divórcio. Não basta a mera aptidão do alimentando para o trabalho, sendo necessária a possibilidade real de efectivo desempenho do mesmo, dada a dificuldade com que pode deparar em encontrar um posto de trabalho em virtude de crise económica e de desemprego ${ }^{29}$. Na verdade, no caso de o alimentando dispor de qualificações profissionais, mas sendo porém escassas ou até nenhumas as suas possibilidades de aplicação, deverá esta circunstância ser apreciada globalmente enquanto impossibilidade real e actual de satisfazer as suas próprias necessidades. O que não significa, todavia, que ao alimentando seja consentido abdicar do exercício de outra actividade remunerada em virtude de esta ser alheia às suas qualificações académicas ou profissionais.

$\mathrm{Na}$ apreciação da necessidade do alimentando, não deve levar-se em linha de conta o facto de este receber alimentos por parte da sua família de sangue, ou de ser por esta acolhido e sustentado. Parece não dever atribuir-se relevância a este apoio material ainda que seja prestado de forma estável, contínua e suficiente. É que este auxílio deriva da mera generosidade e solidariedade dos familiares, não devendo, por conseguinte, influenciar a determinação do direito a alimentos. Além do mais, nos termos do art. 2009..$^{\circ}$ n. ${ }^{\circ}$, al a), a obrigação do ex-cônjuge de prestar alimentos prevalece sobre a dessas outras pessoas.

As necessidades do alimentado podem não ser totalmente satisfeitas com a outorga de uma pensão de alimentos, pois importa levar em conta os recursos do obrigado. Este último tem também as suas próprias necessidades. É capaz de prestar alimentos que não põe

\footnotetext{
29 Coloca-se, nesta sede, a questão de se saber se estaremos - ou não - perante uma desoneração ilegítima do Estado a expensas do outro ex-cônjuge.
} 
em perigo os seus próprios alimentos com a prestação dos mesmos a terceiro. De acordo com o art. 2004..$^{\circ}$ n..$^{\circ}$ 1, "os alimentos serão proporcionados aos meios daquele que houver de prestá-los...”.

Há pois que considerar o património e a capacidade de trabalho do devedor de alimentos, os rendimentos da sua massa patrimonial, assim como o próprio capital (que eventualmente terá de alienar, na justa medida ditada por um princípio de razoabilidade) e, ainda, a viabilidade de obter dinheiro a crédito desde que lhe seja possível pagá-lo dentro de um período razoável. Há que levar em linha de conta as suas obrigações para com outras pessoas, mas já não receitas esporádicas, temporárias e não renováveis.

No que respeita a determinados bens, em princípio improdutivos, há que ponderar a possibilidade que o alimentante tem ou não de realizar o seu valor.

Não tendo como objectivo indemnizar ou compensar o alimentando, a obrigação de alimentos destina-se a auxiliar o cônjuge economicamente mais fraco na obtenção da sua auto-suficiência económica ${ }^{30}$. Deste modo, tem porventura direito a alimentos o ex-cônjuge que não teve a oportunidade de prosseguir a educação ou a carreira profissional em virtude da gestão da vida familiar. Uma vez que não se funda na continuação das obrigações conjugais de natureza económica para além do divórcio, a determinação do montante dos alimentos reabilitadores norteia-se pela necessidade de atribuir, ao ex-cônjuge necessitado, os instrumentos necessários para superar os obstáculos existentes no mercado de trabalho. Pode, pois, dizer-se

30 Designadamente, na aquisição de aptidões ou competências que para o efeito se afigurem necessárias. Cfr. JENNIFER L. MCCOY, Comment: Spousal Sup-port Disorder: An Overview of Problems in Current Alimony Law, in 33 Florida State University Law Review 501, 2005, p. 502-503, 507, 511-512. Refira-se, contudo, a norma do art. $2003 .^{\circ},{ }^{\circ}{ }^{\circ}$, do Cód. Civil, que estabelece que "os alimentos compreendem também a instrução e educação do alimentado no caso de este ser menor". Surge a questão de se saber se, os alimentos ao ex-cônjuge necessitado abrangem ou não a instrução ou educação que lhe permitiram ser auto-suficiente ao abrigo do art. 2016. ${ }^{\circ}$-A, n. ${ }^{\circ}$ 1, do Cód. Civil. 
que o quantum e a duração dos alimentos dependem da conciliação entre a necessidade de permitir ao alimentando um novo começo e a necessidade de limitar as vinculações do ex-cônjuge alimentante.

A obrigação de alimentos deve permitir ao alimentando a autonomia económica necessária a uma existência livre e digna, enquanto este, considerando nomeadamente as suas aptidões académicas e profissionais e as condições do mercado de trabalho, não se encontrar em condições de prover às suas necessidades. Trata-se de assegurar um nível de vida razoável e não apenas o que é indispensável para a sobrevivência ${ }^{31}$ (30). Visa pois consentir ao alimentando um modelo de vida economicamente autónomo, livre e digno de acordo com a consciência social, dissociado das pregressas condições patrimoniais do casal, permitindo ao ex-cônjuge o desenvolvimento da sua personalidade.

\subsection{Carácter temporário 32}

Introduziram-se, efectivamente, em 2008, modificações significativas no regime jurídico da obrigação de alimentos entre ex-cônjuges, estabelecendo-se, desde logo, expressamente o princípio da auto-suficiência de cada um deles, pois cada cônjuge deve prover à sua subsistência depois do divórcio (art. 2016. ${ }^{\circ}$, n. ${ }^{\circ}$ 1, do Cód. Civil). O legislador consagrou assim claramente o dever de cada um dos ex-cônjuges prover à sua subsistência ${ }^{33}$. Este princípio de auto-su-

31 Cfr. Jorge DuARte Pinheiro, o Direito da Família Contemporâneo, aafdl, Lisboa, 2010, p. 696.

32 Para maiores desenvolvimentos, cfr. MARIA JOÃO VAZ TOMÉ, Algumas reflexões sobre a obrigação de compensação e a obrigação de alimentos entre ex-cônjuges, in Estudos em Homenagem ao Professor Doutor Heinrich Ewald Hörster, Almedina, Coimbra, 2012, p. 425 e ss.

33 Este dever não resultava já do art. $2004 .^{\circ}$, n. ${ }^{\circ} 2$ do Cód. Civil. Desta norma resulta apenas que, na determinação do quantum da obrigação de alimentos, se levará em linha de conta a possibilidade de o alimentando prover à sua subsistência. Assim, ao abrigo dessa norma geral do art. $2004 .^{\circ}, \mathrm{n} .{ }^{\circ} 2$, essa possibilidade não elimina forçosamente a necessidade enquanto pressuposto da obrigação de alimentos, diferentemente do que se verifica no âmbito da norma especial do art. 
ficiência é uma consequência necessária da tese do clean break ou da concentração dos efeitos do divórcio. De resto, a sociedade hodierna tem como paradigma o indivíduo autónomo, independente e auto-suficiente. De acordo com a confiança depositada na igualdade (formal) de todos os cidadãos, pressupõe-se que essa autonomia está ao alcance de todos os indivíduos.

Deste princípio de auto-suficiência parece decorrer, ainda que implicitamente, o carácter temporário da obrigação de alimentos. Visando os alimentos permitir a transição para a independência económica, o carácter temporário da obrigação em apreço surge com alguma clareza.

O alimentando não verá as suas necessidades insatisfeitas e o alimentante não será responsável pelo seu futuro. A obrigação de alimentos subsiste pelo período de tempo suficientemente razoável para o alimentando se adaptar às suas novas circunstâncias de vida $^{34}$. Procura-se uma harmonização prática entre as necessidades do alimentando e as vinculações do alimentante, tendo-se também em vista que os efeitos negativos do divórcio se devem repercutir igualmente na esfera de cada um dos cônjuges.

O carácter provisório da obrigação de alimentos parece ser implicado pela própria consagração do referido princípio da auto-suficiência, pela consideração da unidade e coerência jurídico-sistemáticas, pela compreensão da norma em função do seu contexto. Este parece ser o sentido que melhor satisfaz a concordância objectiva e congruência sistemático-prática das opções

$2016 .^{\circ}$, n. $^{\circ} 1$. Em sentido diferente, cfr. RITA LOBO XAVIER, Recentes Alterações ao Regime Jurídico do Divórcio e das Responsabilidades Parentais - Lei N. ${ }^{\circ}$ 61/2008, de 31 de Outubro, Almedina, Coimbra, 2009, p. 18.

${ }^{34}$ A determinação da duração - assim como também do quantum - da obrigação de alimentos, afigura-se especialmente difícil em casamentos de longevidade reduzida. Cfr. JENNIFER L. MCCOY, Comment: Spousal Support Disorder: An Overview of Problems in Current Alimony Law, 33 Florida State University Law Review 501, 2005, p. 523. 
legislativas. Todavia, daquele mesmo princípio de auto-suficiência não resulta, necessariamente, uma duração determinada da obrigação de alimentos.

A norma jurídica, com efeito, como produto normativo-cultural, apenas pode ser compreendida se tivermos em conta a coordenada histórica da sua emergência. Ora tanto a realidade histórico-social como a consciência histórico-social, na sua dimensão cultural e ideológica, apontam no sentido do carácter temporário da obrigação de alimentos entre ex-cônjuges.

$\mathrm{Na}$ verdade, o sistema de divórcio pura constatação da ruptura do casamento e o princípio do clean break ou da concentração dos efeitos do divórcio reflectem uma concepção do casamento enquanto vínculo essencialmente fundado nos afectos e por eles condicionado na sua duração. Neste sistema de divórcio, o cônjuge economicamente dependente é titular de um direito a alimentos menos intenso do que aquele que lhe era conferido no sistema de divórcio por violação culposa dos deveres conjugais ${ }^{35}$.

Depois, o aumento da taxa de divórcio de casamentos de breve duração conduziu à reconfiguração da obrigação de alimentos, inspirando a adopção de uma perspectiva reabilitadora, traduzida na duração temporalmente delimitada desta obrigação e no pagamento una tantum ${ }^{36}$, quando possível, em detrimento da realização de prestações periódicas por tempo indeterminado.

Prevaleceu, assim, entre nós, a concepção reabilitadora ou do carácter temporário da obrigação de alimentos como efeito do divórcio, atendendo como que ao enfraquecimento do fundamento desta obrigação. Da conjugação da norma do art. $2009 .^{\circ}$ n. ${ }^{\circ} 1$, al

35 Cfr. JENNIFER L. MCCOY, Comment: Spousal Support Disorder: An Overview of Problems in Current Alimony Law, in 33 Florida State University Law Review 501, 2005, p. 516-518.

36 No direito comparado, intensifica-se a tendência no sentido da inaplicabilidade da cláusula rebus sic stantibus à obrigação de alimentos que é cumprida una tantum. 
a), com a do art. 2016. ${ }^{\circ}$ n. ${ }^{\circ} 1$, do Cód. Civil, resulta o carácter reabilitador da obrigação de alimentos como efeito do divórcio. Os alimentos reabilitadores visam espelhar a realidade social da participação da mulher no mercado de trabalho, tendo como objectivo a auto-suficiência do ex-cônjuge dependente. Com efeito, a duração limitada da obrigação em apreço surge como resposta às alterações sofridas pelos papéis económico, cultural e familiar da mulher e do homem. Os alimentos temporários propendem a ser a regra no direito do divórcio, tendo por fim o auxílio provisório do ex-cônjuge mulher desprovido das aptidões ou da experiência necessária para o exercício do trabalho remunerado. Tem-se em vista permitir ao alimentando tornar-se economicamente auto-suficiente. Atendendo aos recursos e às necessidades de cada um dos ex-cônjuges, conferindo apoio económico ao ex-cônjuge que se encontre em circunstâncias de maior vulnerabilidade, a sua justificação tende a ser exclusivamente a necessidade - mas uma necessidade que se pretende temporária.

Deve, contudo, conforme referido supra, adoptar-se uma perspectiva realística da auto-suficiência, não subvalorizando os efeitos da debilidade pós-matrimonial de um dos cônjuges, de um lado e, de outro, não sobreavaliando as perspectivas permitidas pelo mercado de trabalho. Por conseguinte, não releva a capacidade laboral genérica e abstracta, mas sim a possibilidade efectiva (atendendo à idade, ao estado de saúde e às competências profissionais do ex-cônjuge) de a concretizar numa actividade remunerada.

Se a obrigação de alimentos está temporalmente limitada, tendo como finalidade permitir ao alimentando alcançar a sua auto-suficiência, muitas frequentemente mediante a sua (re)inserção no mundo do trabalho, há que analisar a sanção para o incumprimento da obrigação de se tornar auto-suficiente, de trabalhar por parte do credor. Por um lado, poderá proceder-se à redução ou mesmo à exclusão dos alimentos, nos termos do art. 2012..$^{\circ}$, considerando 
que se concederam alimentos ao necessitado no pressuposto de que este se iria empregar ulteriormente de acordo com a ratio do art. $2004 .^{\circ}$, n. $^{\circ} 2$ (verdadeira e própria necessidade). Se, a posteriori, se verifica uma inércia da sua parte, terá ocorrido uma alteração das circunstâncias, porquanto as circunstâncias vigentes ao tempo da fixação da obrigação de alimentos permitiam o seu ingresso no mercado de trabalho. Um verdadeiro e próprio estado de necessidade apenas existiu no momento imediatamente subsequente ao divórcio, quando ao credor não era possível encontrar um lugar no mercado de trabalho. A permanência numa situação de dependência não deve estar sujeita à inércia voluntária do interessado. Por outro lado, poderá dizer-se que quem, apesar de não possuir bens, tiver a possibilidade concreta e não apenas abstracta de se manter através do seu trabalho - excepto se o emprego for inadequado para a sua idade ou saúde, número e idade de filhos ou outras condições relevantes - não se encontra em verdadeira necessidade. Contudo, no caso de a remuneração auferida pelo alimentando se revelar insuficiente, a obrigação de alimentos, ainda que reduzida no seu montante, permanece (arts. 2004..$^{\circ}$ e 2016..$^{\circ}$ n. ${ }^{\circ}$ 2, e art. 2016. $.^{\circ}-\mathrm{A}$, n. ${ }^{\circ}$ 1, do Cód. Civil).

Em qualquer caso, a obrigação não deveria ter limites temporais no caso de idade já avançada do cônjuge necessitado e de casamento de longa duração ${ }^{37}$.

A partilha, em partes iguais, do património comum do casal e a obrigação de alimentos de carácter temporário visam a realização do princípio do clean break entre os ex-cônjuges. Com efeito, esta ruptura dificilmente teria lugar se um dos ex-cônjuges ficasse indefinidamente obrigado a prestar alimentos ao outro.

37 Cfr. Maintenance Principles, Section 5.07 (1) (a). 


\subsection{Art. $2016 .^{\circ}-\mathrm{A}$, n. $^{\circ}$ 3, do Cód. Civil ${ }^{38}$}

O direito a alimentos é reconhecido apenas ao ex-cônjuge que se revele incapaz de alcançar a auto-suficiência. A obrigação de alimentos é objecto de limitação na sua duração, correspondendo ao período de tempo estritamente necessário para permitir ao alimentando alcançar a independência alimentar.

Os alimentos reabilitadores têm pois como objectivo conferir os recursos necessários, durante o período de tempo requerido, para que o alimentando se torne auto-suficiente.

A auto-suficiência não é, porém, apreciada no contexto do padrão de vida previamente gozado pelos cônjuges (art. 2016. ${ }^{\circ}-\mathrm{A}, \mathrm{n} .^{\circ} 3$, do Cód. Civil), pois adopta-se o princípio de que o credor de alimentos não tem o direito de manter o trem de vida de que gozou enquanto esteve casado, independentemente da maior ou menor duração do casamento. O matrimónio que não durar para sempre não pode garantir um certo nível de vida para sempre, mesmo que haja tido uma longa duração. Trata-se de um modelo de alimentos temporários, baseado nas necessidades implicadas por uma vida autónoma e digna do alimentando 39.

Refutando-se a ultra-actividade de um acordo celebrado em vista da gestão de uma sociedade conjugal agora extinta, o ex-cônjuge alimentando não tem o direito de manter o trem de vida adoptado na vigência do casamento. Acresce a consideração das implicações económicas da existência, após a dissolução do casamento, de dois ménages distintos. Estabelece-se assim que a necessidade, enquanto conceito jurídico, não abrange o padrão de vida adoptado na vigên-

\footnotetext{
38 Para maiores desenvolvimentos, cfr. MARIA JOÃO VAZ TOMÉ, Algumas reflexões sobre a obrigação de compensação e a obrigação de alimentos entre ex-cônjuges, in Estudos em Homenagem ao Professor Doutor Heinrich Ewald Hörster, Almedina, Coimbra, 2012, p. 425 e ss.

39 Cfr. JENNIFER L. MCCOY, Comment: Spousal Support Disorder: An Overview of Problems in Current Alimony Law, in 33 Florida State University Law Review 501, 2005, p. 523.
} 
cia do casamento (art. 2016. ${ }^{\circ}$-A, n..$^{\circ}$ 3, do Cód. Civil), ignorando-se, para este efeito, a maior ou menor duração do casamento, a idade do cônjuge necessitado e a discrepância de rendimentos entre os ex-cônjuges. Desconhece-se, de algum modo, que a idade afecta a aptidão para se ser auto-suficiente. Princípios de equidade justificariam, em determinadas circunstâncias, a manutenção do padrão de vida matrimonial. Num casamento de longa duração, o cônjuge que durante muito tempo foi exclusivamente dona de casa e/ou mãe, arca, em geral, com riscos económicos consideravelmente maiores do que o outro cônjuge aquando da dissolução do casamento.

O ex-cônjuge alimentante, por seu turno, tem o direito de manter o trem de vida de que gozava na vigência do casamento. Por isso, ao que parece, a obrigação de alimentos perante o ex-cônjuge não deve ameaçar o seu padrão de vida. Poderá, contudo, levantar-se a questão de se saber se o princípio da solidariedade pós-conjugal, enquanto fundamento da obrigação em apreço, não será susceptível de, em situações de grave desequilíbrio, permitir a limitação daquele mesmo direito.

\subsection{Art. $2016 .^{\circ}$-A, n. ${ }^{\circ} 1$, do Cód. Civil ${ }^{40}$}

O art. 2016. ${ }^{\circ}$-A, n. ${ }^{\circ}$ 1, do Cód. Civil, enquanto norma especial, consagra uma disciplina nova ou diferente para este círculo mais restrito de pessoas ou de relações, "especializando" a norma geral do art. 2004. ${ }^{\circ}$ A enumeração ali feita das circunstâncias a levar em linha de conta é meramente exemplificativa, como resulta com toda a clareza do.$^{\circ} 1$, in fine, do mesmo preceito. Confere-se assim uma ampla margem de discricionaridade ao tribunal.

40 Para maiores desenvolvimentos, cfr. MARIA JOÃO VAZ TOMÉ, "O direito à pensão de reforma enquanto bem comum do casal", Coimbra, Coimbra Editora, 1997, p. 329 e ss.; MARIA JOÃO VAZ TOMÉ, Algumas reflexões sobre a obrigação de compensação e a obrigação de alimentos entre ex-cônjuges, in Estudos em Homenagem ao Professor Doutor Heinrich Ewald Hörster, Almedina, Coimbra, 2012, p. 425 e ss. 
A ausência de consenso sobre o fundamento e a natureza da obrigação de alimentos como efeito do divórcio conduz a que o legislador proceda a uma enumeração exemplificativa dos factores a ter em conta na sua determinação (art. 2016. ${ }^{\circ}$ A, n. ${ }^{\circ} 1$, do Cód. Civil) ${ }^{41}$.

Assim, para a fixação do montante da pensão releva "a duração do casamento, a colaboração prestada à economia do casal, a idade e estado de saúde dos cônjuges, as suas qualificações profissionais e possibilidades de emprego, o tempo que terão de dedicar, eventualmente, à criação de filhos comuns, os seus rendimentos e proventos, um novo casamento ou união de facto e, de modo geral, todas as circunstâncias que influam sobre as necessidades do cônjuge que recebe os alimentos e as possibilidades do que os presta".

A referência à "colaboração à economia do casal" ilustra, de algum modo, que o legislador não terá pretendido desencorajar a assunção de tarefas domésticas e de cuidado dos filhos na vigência da sociedade conjugal.

A colaboração gratuita prestada por um cônjuge à actividade comercial, industrial ou profissional do outro cônjuge, enquanto elemento relevante da fixação do quantum da obrigação de alimentos suscita a dificuldade da sua delimitação face ao dever de cooperação, previsto nos arts. $1672 .^{\circ}$ e $1674 .^{\circ}$, vigente na pendência do casmento. Poderá dizer-se que essa linha de fronteira se encontra no conceito de enriquecimento sem causa, cuja verificação se pretende evitar após a cessação da comunhão de vida característica do casamento. Aquela colaboração integrará pois o conceito de "colaboração à economia do casal" ou, então, a parte final do art. $2016 .^{\circ}-\mathrm{A}, \mathrm{n} .^{\circ} 1$.

$\mathrm{O}$ cuidado prestado a parentes durante o casamento e a filhos nascidos fora desse casamento parece caber no art. $2016 .^{\circ}-\mathrm{A}, \mathrm{n} .{ }^{\circ} 1$, in fine.

41 Cfr. AMERICAN LAW InSTITUTE, Principles of the Law of Family Dissolution: Analysis and Recommendations $§ 5.02$ (2002). 
Tal como na apreciação da necessidade do alimentando, também em sede de fixação do montante da pensão de alimentos não deve levar-se em linha de conta o facto de o alimentando receber alimentos por parte da sua família de sangue, ou de ser por esta acolhido e sustentado. Conforme referido supra, não deve atribuir-se relevância a este apoio material ainda que seja prestado de forma estável, contínua e suficiente, pois trata-se de generosidade e solidariedade dos familiares e que, por isso mesmo, não deve influenciar o montante da pensão de alimentos. Por outro lado, de acordo com o art. $2009 .^{\circ}$, n. $^{\circ} 1$, al a), a obrigação do ex-cônjuge de prestar alimentos prevalece sobre a dessas outras pessoas.

A mesma norma refere também o tempo que os cônjuges terão de dedicar à criação de filhos comuns. Esta circunstância deve, mutatis mutandis, ser levada em linha de conta mesmo que os filhos já sejam maiores de idade. Na verdade, a dependência dos filhos perante os pais não termina, em geral, com a sua maioridade, conforme o demonstra o art. 1880..$^{\circ}$ Por outro lado, o legislador não estabeleceu a distinção entre filhos menores e maiores no âmbito da obrigação de alimentos como efeito do divórcio.

Ao que parece, o legislador tem aqui em vista o novo casamento entretanto celebrado pelo alimentante, quando o direito a alimentos é, porventura, exercido após o decurso do prazo internupcial ou quando se cure de alterar os alimentos fixados (art. 2012. ${ }^{\circ}$ ). Não se trata da celebração de novas núpcias pelo alimentando, porquanto esta é causa de cessação da obrigação de alimentos, conforme o art. 2019..$^{\circ}$ do Cód. Civil. O mesmo se refira a propósito da união de facto, que é aquela do devedor, pois a do credor, de acordo com a mesma norma do art. 2019. ${ }^{\circ}$, constitui causa de cessação da obrigação de alimentos ${ }^{42}$. Apesar de os unidos de facto não estarem

42 Já antes da reforma de 2008, defendia, a propósito da união de facto do credor de alimentos, não ter sido certamente intenção do legislador favorecer a 
reciprocamente obrigados à assistência e cooperação, as condições económicas de facto do alimentante deverão ser consideradas na fixação do montante da obrigação de alimentos. Como que se atende às expectativas de facto do unido de facto, não importando apenas as obrigações legais de alimentos perante outras pessoas de que o devedor seja titular.

Poderia dizer-se que as circunstâncias que o tribunal deve apreciar ao abrigo do art. 2016. ${ }^{\circ}$-A , n. ${ }^{\circ}$ 1, do Cód. Civil, e cuja harmonização com a actual função da obrigação de alimentos suscita algumas dificuldades, não têm qualquer papel na fase de atribuição do direito (que é condicionado, como nas obrigações alimentares puras, pela falta de meios para se ser auto-suficiente), respeitando exclusivamente à quantificação da prestação alimentar. Todas aquelas circunstâncias, que dificilmente se conciliam com a função que esta obrigação é hoje chamada a desenvolver, não produziriam qualquer efeito na fase da atribuição do direito, influenciando apenas o respectivo quantum ${ }^{43}$.

Surge, no entanto, uma qualquer contradição intrínseca entre a recusa de relevância aos critérios plasmados no art. $2016 .^{\circ}-\mathrm{A}, \mathrm{n} .^{\circ} 1$, do Cód. Civil em sede de determinação do direito a alimentos

união de facto em detrimento do matrimónio. A união de facto, não sendo embora fonte de relações familiares, não relevando assim do ponto de vista jurídico o que o credor aufere em virtude dessa união, recebendo por mero favor, importa em sede de obrigação de alimentos do ponto de vista material. A união de facto do credor de alimentos deveria então ser considerada como causa de cessação da obrigação de alimentos quer em virtude da interpretação extensiva da expressão "novo casamento" (art. 2019. ${ }^{\circ}$ do Cód. Civil), quer por força da aplicação analógica da norma que prevê o novo casamento do credor como causa de extinção (art. 2019. ${ }^{\circ}$ do Cód. Civil), quer por força do art. $2013 .^{\circ}, \mathrm{n} .^{\circ} 1$, al b), do Cód. Civil (desnecessidade). MARIA JOÃO VAZ TOMÉ, $O$ direito à pensão de reforma enquanto bem comum do casal, Coimbra Editora, Coimbra, 1997, p. 375 e ss.

43 Cfr. CARLO G. TERRANOVA, Contributo ad una teoria unitária delle prestazioni alimentari, Edizioni Scientifiche Italiane, Napoli, 2004, p. 141-142.

A enunciação de um amplo leque de critérios, no art. $2016 .^{\circ}-\mathrm{A}, \mathrm{n} .{ }^{\circ}{ }^{1}$, do Cód. Civil, como que indicia alguma incerteza do legislador sobre o fundamento e a natureza da obrigação de alimentos entre ex-cônjuges. 
(relativamente ao an) de um lado e, de outro, a consideração da sua importância para o não reconhecimento, em dadas condições, do mesmo direito (art. 2016..$^{\circ}$ n..$^{\circ} 3$, do Cód. Civil).

$\mathrm{Na}$ verdade, os critérios referidos no n. ${ }^{\circ} 1$ do art. 2016. ${ }^{\circ}$-A acabam por ter uma verdadeira e própria eficácia concausal, desempenhando aquela função causal concorrente, cuja admissibilidade substancial (ainda que implícita) conduz à consideração de todos esses critérios enquanto pressuposto do reconhecimento do direito a alimentos. Poderia assim dizer-se que os critérios constantes do art. 2016. ${ }^{\circ}$-A, n. ${ }^{\circ} 1$, são, em último recurso, também determinantes do próprio reconhecimento do direito a alimentos, com a consequência de que o juízo sobre o an da obrigação de alimentos perde a sua conotação autónoma e preliminar ${ }^{44}$.

Esta conclusão afigura-se, contudo, incompatível com uma eventual intenção do legislador de eliminar, na atribuição do direito a alimentos, aspectos de natureza não exclusivamente alimentar.

Considerando o papel causal de apreciações de tipo contributivo, assim como a relevância de outros parâmetros quer na atribuição, quer na quantificação dos alimentos, pode afirmar-se insuperável o limite do estado de necessidade do ex-cônjuge e, por isso mesmo, nem a brevíssima duração do casamento seria susceptível de se traduzir num motivo de recusa do mínimo vital ${ }^{45}$.

Deste modo se acaba por admitir, ainda que implicitamente, que decorre de uma concepção estritamente alimentar da obrigação em apreço - à luz da qual prevalece, coerentemente, de forma exclusiva, a apreciação da deterioração, em dependência do divórcio, das condições económicas do cônjuge e da exigência correspondente de restabelecer um certo equilíbrio - o risco de perduração daque-

\footnotetext{
${ }^{44}$ Cfr. ENRICO QUADRI, Famiglia e Ordinamento civile, G. Giappichelli Editore, Torino, 1999, p. 360-361.

45 Cfr. MARCella Fortino, Diritto di Famiglia, I Valori, I Principi, Le Regole, Giuffrè Editore, Milano, 1997, p. 331.
} 
las posições de pura renda que o legislador pretendeu eliminar. Consequentemente, em ordem a evitar a verificação de um tal risco, a atribuição do direito a alimentos, longe de estar subordinada apenas à situação de necessidade de um dos cônjuges, encontra-se indissociavelmente ligada à consideração de todos os elementos indicados pelo legislador no art. 2016. ${ }^{\circ}$-A, do Cód. Civil ${ }^{46}$. A consideração destes critérios normativos é, efectivamente, susceptível de conduzir à exclusão da obrigação de alimentos, nos termos do art. 2016. ${ }^{\circ}$, n. $^{\circ}$ 3, do Cód. Civil.

Trata-se de uma ponderação complexa, elástica e global (inevitavelmente condicionada pela apreciação da duração do casamento, destinada a assumir, contra qualquer tentativa redutora, o papel fundamental de verdadeiro e próprio "filtro" da relevância concreta dos diversos critérios normativos) da ordem familiar real e do grau de interpenetração das esferas pessoais e patrimoniais dos cônjuges, ordem esta passível de criar expectativas cuja tutela se consubstancia no justo reconhecimento da participação numa verdadeira comunhão de vida - num consortium omnis vitae - enquanto fundamento da pretensão de autonomia e dignidade do cônjuge economicamente mais vulnerável. Por conseguinte, os critérios normativos consagrados no art. 2016. ${ }^{\circ}-\mathrm{A},{ }^{\circ}{ }^{\circ} 1$, do Cód. Civil, não relevam apenas em sede de determinação da medida da obrigação de alimentos, podendo conduzir também a uma eventual exclusão da mesma (art. 2016. ${ }^{\circ}$, n. ${ }^{\circ} 3$, do Cód. Civil). Consubstanciam variáveis susceptíveis de actuarem em sentido negativo (exclusão do direito a alimentos) ${ }^{47}$, mas dificilmente em sentido positivo. Com efeito, não se verificando a facti-species do art. 2016. ${ }^{\circ}$, n. $^{\circ} 3$, do Cód. Civil, o ex-cônjuge necessitado terá sempre, independentemente de qualquer valoração,

\footnotetext{
46 Cfr. ENRICO QUADRI, Famiglia e Ordinamento civile, G. Giappichelli Editore, Torino, 1999, p. 362-363.

47 Cfr. Gabriella Autorino Stanzione, Diritto de Famiglia, Torino, G. Giappichelli Editore, 1997, p. 182.
} 
direito a alimentos que lhe permitam um padrão de vida autónomo e digno mas em caso algum terá direito à manutenção do trem de vida adoptado na vigência do casamento. Acresce que a medida dos alimentos deve ser proporcional aos rendimentos do alimentante, não podendo ultrapassar esta referência essencial, sob pena de limitar de modo inadmissível a esfera de liberdade pessoal do obrigado.

A existência de uma ampla margem de discricionaridade judicial surge como inevitável na disciplina vigente. Representa a contrapartida forçosa da preservação daquela característica do direito a alimentos enquanto resposta dúctil para os diversos modelos concretos de casamento. Esta vontade parece razoavelmente radicada na necessidade de levar em linha de conta a realidade representada pela variedade de modelos familiares difundidos numa sociedade rica em contrastes no plano económico-social.

O legislador muito dificilmente poderia ir para além de uma previsão pragmática de uma extensa enunciação de critérios a levar em conta no caso concreto.

\subsection{Art. $2016{ }^{\circ}-\mathrm{A}$, n. $^{\circ}$ 2, do Cód. Civil}

Estabelece-se aqui a prevalência de qualquer obrigação de alimentos relativamente a filhos do devedor em detrimento da obrigação emergente do divórcio em favor do ex-cônjuge. Esta solução encontra-se em conformidade com o direito sucessório porquanto, diferentemente dos filhos, o ex-cônjuge alimentando não é herdeiro legal do alimentante. Nessa preferência atende-se a que, por via de regra, os filhos menores são naturalmente incapazes de criar a sua autosuficiência e de procurar os meios necessários à sua subsistência (art. 2009. ${ }^{\circ}$ n. ${ }^{\circ} 1$, al c), e n. ${ }^{\circ}$, do Cód. Civil). O mesmo se poderá dizer a respeito dos filhos maiores que ainda não tenham completado vinte e cinco anos de idade, nem a sua educação ou formação profissional (arts. $1880 .^{\circ}$ e $1905 .^{\circ}$, n. $^{\circ} 2$, do Cód. Civil). 


\subsection{Alteração ${ }^{48}$}

O princípio do clean break ou da concentração dos efeitos do divórcio no momento da dissolução do casamento foi sempre objecto de algumas rectificações.

De acordo com a sua natureza alimentar, a obrigação em apreço, encontra-se fatalmente sujeita a modificações. O princípio da solidariedade pós-conjugal, enquanto último reduto da vida vivida em comum, justifica uma certa permeabilidade entre as situações económicas dos ex-cônjuges.

O art. 2012. ${ }^{\circ}$ do Cód. Civil não consagra, como requisito da sua aplicação, ao contrário do art. $437 .^{\circ}$, o carácter substancial da alteração das circunstâncias.

A pensão de alimentos é, pela sua própria natureza, essencialmente variável. Independentemente da forma da fixação do seu quantum - judicial ou convencional -, ela é sempre provisória. Baseando-se essa determinação na situação actual (ou previsível) das partes, ela é passível de modificação em virtude de alteração daquela situação ${ }^{49}$.

Já se sustentou que para se verificar a diminuição do montante da obrigação de alimentos basta que o obrigado piore de circunstâncias ou que o credor melhore. $\mathrm{O}$ aumento do mesmo montante, por seu turno, requer a verificação cumulativa da melhoria da situação do obrigado e o agravamento das condições do credor. Pensamos,

48 Para maiores desenvolvimentos, cfr. MARIA JOÃO VAZ TOMÉ, $O$ direito à pensão de reforma enquanto bem comum do casal, Coimbra Editora, Coimbra, 1997, p. 350 e ss, 366 e ss.

Não se cura aqui do aumento ou da redução das necessidades do alimentando decorrentes, respectivamente, da desvalorização ou da valorização da moeda. A obrigação de alimentos é uma dívida de valor e não uma dívida pecuniária em sentido estrito, sendo o dinheiro apenas o substituto ou sucedâneo do objecto inicial da prestação, porquanto é o valor que determina a quantidade. Trata-se de uma dívida que tem por objecto a atribuição de um determinado poder aquisitivo.

49 Também o próprio modo de prestar os alimentos devidos é susceptível de modificação em virtude de alteração superveniente das circunstâncias. 
contudo, que o aumento da pensão de alimentos não exige necessariamente que o obrigado melhore de circunstâncias. Com efeito, se este, já ao tempo da fixação inicial da obrigação de alimentos disfrutava de uma situação económica desafogada, havendo-a entretanto conservado, é suficiente para o aumento do quantum da obrigação de alimentos que as condições do credor piorem.

Em princípio, o aumento da pensão de alimentos tem lugar no caso de o credor piorar de circunstâncias e de o devedor dispor de recursos suficientes de um lado e, de outro, de as necessidades do credor não encontrarem satisfação cabal e o devedor entretanto beneficiar de um acréscimo patrimonial: trata-se de duas hipóteses autónomas. O aumento dos recursos do devedor não implica, por si mesmo, o acréscimo da pensão de alimentos, pois é a necessidade que essencialmente rege e justifica a obrigação de alimentos, constituindo os recursos apenas o meio idóneo de lhe fazer face.

Todo e qualquer incremento patrimonial sofrido pelo património do credor redunda na aplicação da norma do art. 2013. ${ }^{\circ}$, al b), in fine, ou, pelo menos, na do art. 2012. ${ }^{\circ}$, no sentido da redução da pensão de alimentos.

Se o credor desenvolver entretanto uma actividade desordenada ou irregular, bastar-lhe-á abandoná-la para assegurar a sua subsistência. Talvez seja de reduzir, nesse caso, a pensão de alimentos ao mínimo vital. Se essas condutas são adoptadas pelo devedor, nem por isso deve reduzir-se o montante da pensão de alimentos. De facto, a abstenção do exercício de tais actividades revela-se suficiente para lhe permitir cumprir a obrigação a que se encontra adstrito.

Parece-nos que se a revisão da pensão de alimentos é susceptível de afectar para cima ou para baixo uma prestação já fixada, ela é também passível de atingir uma prestação igual a zero, ora porque foi recusada, devido à ausência dos requisitos do direito a alimentos, ora porque não foi requerida, tendo sempre em vista uma situação 
sujeita a evolução. Esta solução encontra-se em conformidade com a natureza alimentar da obrigação em apreço e com o seu fundamento num princípio de solidariedade pós-conjugal.

A consideração do novo casamento ou da união de facto do devedor - que não constitui causa de cessação da obrigação em apreço - no âmbito da revisão do montante dos alimentos, provavelmente em vista da sua redução, parece acertada ${ }^{50}$. O alimentante tem o direito, constitucionalmente tutelado de casar (art. 36. ${ }^{\circ}$, n. $^{\circ}$ 1, da Constituição) e, por conseguinte, de recasar. Não se aplicaria o princípio priore in tempore potiore iure. Tanto as novas núpcias como a união de facto do alimentante são susceptíveis de alterar as suas condições económicas e, assim, de afectar negativamente a sua capacidade de prestar alimentos ao ex-cônjuge. Muito em especial, esta conclusão encontra apoio no elemento sistemático da interpretação da lei51, na consideração da unidade e coerência jurídico-sistemáticas, na compreensão da norma em função do seu contexto. Este parece ser o sentido que melhor satisfaz a concordância objectiva e congruência sistemático-prática das opções legislativas. Está em causa a consideração das outras disposições que formam o complexo normativo do instituto em que se integra a norma interpretanda, isto é, que regulam a mesma matéria (contexto da lei) ${ }^{52}$, assim como a sua consonância com ou

\footnotetext{
${ }^{50}$ No caso de a obrigação de alimentos sobreviver ao novo casamento do devedor, o património comum dos cônjuges não responde pela dívida em causa, conforme decorre do art. $1692 .^{\circ}$ do Cód. Civil. Resta, contudo, a possibilidade de aplicação do art. $1696 .^{\circ}$, do mesmo corpo de normas.

51 Deve levar-se em linha de conta a norma enquanto harmonicamente integrada na unidade do sistema jurídico (art. $99^{\circ}$, n. ${ }^{\circ}$ 1, do Cód. Civil). A consideração deste elemento sempre derivaria do princípio da coerência valorativa ou axiológica da ordem jurídica. Pode, a este propósito, falar-se em "referência do sentido de cada norma ao ordenamento jurídico global". Cfr. KARL ENGISH, Introdução ao Pensamento Jurídico, Fundação Calouste Gulbenkian, Lisboa, 1988, p. 166 e ss.

52 Assim como a consideração de disposições legais que regulam problemas normativos paralelos ou institutos afins (lugares paralelos) e o lugar sistemático que compete à norma intepretanda no ordenamento global.
} 
espírito ou unidade intrínseca de todo o ordenamento jurídico. Baseia-se no postulado da coerência intrínseca do ordenamento, designadamente no facto de que as normas contidas numa codificação obedecem, por princípio, a um pensamento unitário ${ }^{53}$. Deve, assim, levar-se em linha de conta a norma do art. $2016 .^{\circ}-\mathrm{A}, \mathrm{n} .^{\circ} 1$, do Cód. Civil, que na fixação do montante dos alimentos, atribui relevância ao novo casamento ou união de facto do alimentante (contexto da lei). Por outro lado, o princípio da coerência valorativa da ordem jurídica implica a consideração do casamento enquanto vínculo essencialmente fundado nos afectos e, por isso, livremente dissolúvel, de acordo com o sistema de divórcio pura constatação da ruptura e o princípio da concentração dos efeitos do divórcio, assim como o princípio de auto-suficiência de cada um dos ex-cônjuges.

A alteração in peiús dos rendimentos do devedor, porque este decide abdicar ou reduzir a sua actividade remunerada, alterar o seu objecto ou a modalidade do seu exercício é provavelmente passível de conduzir à redução do montante da pensão de alimentos. Tratase de escolha livre do ex-cônjuge, não prevalecendo o princípio de solidariedade pós-conjugal sobre a liberdade pessoal do sujeito no que toca à condução da sua própria vida, à realização das suas aspirações ${ }^{54}$.

Por último, atendendo à sua ratio, pensamos que o art. 2012. ${ }^{\circ}$ é aplicável tanto perante a ocorrência de eventos supervenientes como também perante o conhecimento superveniente de circunstâncias anteriores.

53 Cfr. JOÃO BAPTISTA MACHADO, Introdução ao Direito e ao Discurso Legitimador, Almedina, Coimbra, 1994, p. 183.

54 Cfr. Massimo escher/Carmelo Paladino, Il Diritto ao Mantenimento, Aspetti patrimonial della crisi della famiglia, Experta edizioni, Forli, 2010, p. 196-197. 


\subsection{Algumas causas de cessação55}

O novo casamento ou união de facto do alimentante são susceptíveis de conduzir à cessação do vínculo alimentar que o liga ao seu ex-cônjuge por carência de recursos, em conformidade com o art. 2013..$^{\circ}$ n. ${ }^{\circ}$ 1, al. b), do Cód. Civil. É que a obrigação de alimentos centra-se na necessidade, sendo os recursos do devedor apenas um meio de satisfazer essa necessidade. $\mathrm{O}$ novo casamento ou união de facto do obrigado não consubstanciam causa de cessação da obrigação de alimentos, pois não se encontram previstos nos arts. $2013 .^{\circ}$ e $2019 .^{\circ}$ Contudo, a extinção da dívida alimentar pode resultar do art. $2013 .^{\circ},{ }^{\circ}{ }^{\circ} 1$, al. b), ou seja, da falta de recursos do devedor para cumprir.

Exemplos de situações passíveis de preencherem o conceito indeterminado do art. 2019. (se o alimentando "se tornar indigno do benefício pelo seu comportamento moral") são a violação do direito à honra, à liberdade ou à integridade física da outra parte, assim como a prática de delitos similares, a instigação nos filhos de sentimentos de desprezo e de rancor pelo alimentante, a utilização de dinheiro em campanha difamatória contra o devedor, a tentativa de homicídio, a denúncia caluniosa, etc. De resto, alguns destes factos seriam já subsumíveis à norma do art. $2013 .^{\circ}$, n. ${ }^{\circ} 1$, al. c), do Cód. Civil ("Quando o credor viole gravemente os seus deveres para com o obrigado"). O mesmo sucede quando o credor viola os interesses patrimoniais do devedor ${ }^{56}$. Da conjugação das normas dos arts. 2016. ${ }^{\circ}$, n. $^{\circ}$ 3, e do art. 2019. ${ }^{\circ}$, do Cód. Civil, parece

55 Para maiores desenvolvimentos, cfr. MARIA JOÃO VAZ TOMÉ, O direito à pensão de reforma enquanto bem comum do casal, Coimbra Editora, Coimbra, 1997, p. 364, 378 e ss.

56 Por exemplo, quando macula a imagem do devedor junto da sua entidade patronal e, assim, coloca em perigo o seu posto de trabalho. Uma tal conduta viola o dever de respeito bilateral que, tal como a obrigação de alimentos como efeito do divórcio, constitui expressão da solidariedade pós-conjugal. Parece que não deve requerer-se a existência de um dano concreto. 
resultar que a conduta do alimentante, susceptível de extinguir a obrigação de alimentos, deve ser posterior e não contemporânea do divórcio ${ }^{57}$. Também a prática do jogo e o deboche poderão implementar o mesmo conceito indeterminado, sendo assim causa de cessação da obrigação de alimentos. O mesmo se refira a propósito da verificação de algumas das situações previstas nos arts. $2034 .^{\circ} \mathrm{e}$ 2166. ${ }^{\circ}$ do Cód. Civil ${ }^{58}$.

Já se afirmou ${ }^{59}$ que, em virtude de a obrigação de alimentos ser pessoal ao credor e ao devedor, ela não se transmite aos herdeiros de qualquer deles, tal como dispõe o art. $2013 .^{\circ},{ }^{\circ}{ }^{\circ} 1$, al a), do Cód. Civil. De um lado, o direito a alimentos não se transmite aos herdeiros do credor porque se destina a satisfazer as necessidades do credor e não as dos seus herdeiros. De outro lado, a obrigação de alimentos não se transmite aos herdeiros do devedor porquanto estes podem não gozar da possibilidade de prestar alimentos. De mais a mais, a obrigação de alimentos está condicionada pelos recursos do seu devedor e não pelos dos seus herdeiros. Acresce que o vínculo especial que funda a obrigação em apreço pode não ter lugar entre os herdeiros do devedor e o credor.

Todavia, o Cód. Civil de 1867 consagrava, no art. 176. ${ }^{\circ}$, o carácter transmissível da obrigação de alimentos. Por outro lado, encontrava-se muito enraizada na doutrina e na jurisprudência a ideia da hereditabilidade dessa obrigação, podendo tal solução fundar-se no

\footnotetext{
57 Salvo se essa conduta, contemporânea do divórcio, for considerada como "razão manifesta de equidade" para recusar ab initio o direito a alimentos ao alimentando.

58 No direito anterior, as causas de deserdação eram igualmente causas de cessação da obrigação de alimentos. O facto de o legislador omitir agora qualquer referência à norma reguladora dos casos de deserdação não permite ao intérprete ignorá-la na implementação do conceito indeterminado em apreço. O legislador, mediante a técnica legislativa a que recorreu, teve em vista conceder uma ampla margem de discricionariedade ao tribunal, em virtude da natureza das situações em causa, não pretendendo afastar o eventual auxílio das normas do direito das sucessões.

59 Cfr. Adriano VAz SERra, Obrigação de Alimentos, in Boletim do Ministério da Justiça, 108, 1961, p. 171.
} 
art. 1231. ${ }^{\circ}$, segundo o qual o cônjuge que, por morte do outro, se achasse sem meios de subsistência, tinha o direito de ser alimentado pelos rendimentos dos bens deixados pelo de cujus $^{60}$.

Poderia, nesta sede, em vista a não prejudicar o carácter pessoal ao alimentante, aderir-se à tese que estabelece a distinção entre encargo da herança - onde se encontraria a solução para o problema da necessidade do ex-cônjuge que não se extingue com a morte do devedor ${ }^{61}$ - e transmissibilidade por morte da obrigação de alimentos. Além disso, o art. 2020. ${ }^{\circ}$, concede ao membro sobrevivo da união de facto um direito a alimentos sobre a herança do de cujus, verificados os requisitos previstos nessa norma. $\mathrm{O}$ art. $2018 .^{\circ}$ atribui ao cônjuge sobrevivo o direito de apanágio que se traduz também num direito a alimentos a regular pelos princípios gerais nesta matéria.

\section{Conclusão}

Pode afirmar-se que a obrigação de alimentos como efeito do divórcio é uma espécie do género obrigação de alimentos. Está em causa a tutela existencial de um dos cônjuges que, após a extinção do vínculo conjugal, se encontra em situação de necessidade.

É devida quando um dos ex-cônjuges se encontra em necessidade. O pressuposto para o reconhecimento do direito a alimentos não é constituído pela falta absoluta de meios de sustento, mas pela ausência de meios adequados a consentir ao ex-cônjuge um teor de vida autónomo e digno.

60 Manifestando opinião contrária, cfr. Francisco MANUEl PEREIRA COELHO, Curso de Direito da Família, I - Direito Matrimonial, Coimbra, 1965, p. 538-539. Este autor afirma que "Tal obrigação funda-se na relação pessoal que liga os divorciados um ao outro, e deve, pois, logicamente, extinguir-se quando por morte de um deles essa relação se extingue...”.

${ }^{61}$ Alíás, provavelmente na linha da solução adoptada no art. $2011 .^{\circ}$, n. ${ }^{\circ}$ 2, do Cód. Civil. 
A análise das circunstâncias económicas dos cônjuges permite determinar o an debeatur. Por seu turno, a averiguação dos respectivos rendimentos e proventos consente a quantificação do conteúdo da prestação. Isto não obsta a que a apreciação dos recursos se encontre já compreendida naquela das circunstâncias, subsistindo entre ambos os juízos uma relação de moderação.

A eventual insuficiência dos alimentos para assegurar o sustento adequado ao necessitado pode dar lugar a que este peça alimentos a outros sujeitos, nos termos do art. 2009. do Cód. Civil.

Preconiza-se, por outro lado, a preferência pela partilha do património comum do casal em detrimento da obrigação de alimentos como meio de satisfação das necessidades económicas do ex-cônjuge. Apenas no caso de insuficiência desse património e de o necessitado não encontrar actividade remunerada que lhe consinta alcançar a auto-suficiência, ou de se dedicar ao cuidado dos filhos no período subsequente ao divórcio, teria lugar a obrigação de alimentos ${ }^{62}$.

62 Havendo filhos menores, a desconsideração do padrão de vida gozado na vigência do casamento, susceptível de originar disparidades substanciais entre as condições de vida de cada um dos ex-cônjuges, repercute-se no seu modus vivendi. Estão em jogo as necessidades dos filhos cujo padrão de vida é, em ultimo recurso, determinado por aquele do progenitor com quem residem. Não se teve a preocupação de equiparar os rendimentos disponíveis dos ex-cônjuges após a consideração da obrigação de alimentos perante os filhos.

As teorias da "associação parental" fundam a obrigação de alimentos entre ex-cônjuges nos deveres parentais e não na relação matrimonial per se. De acordo com estas teorias, esta obrigação de alimentos encontra a sua justificação, não apenas na compensação do progenitor a quem a guarda dos filhos é atribuída, mas também no reconhecimento da obrigação de o progenitor proporcionar aos filhos um padrão de vida análogo ao seu.

Independentemente da aceitação das teorias da "associação parental" na sua plenitude, a necessidade de uma obrigação de alimentos mais generosa perante o alimentando a quem é confiada a guarda dos filhos menores, ainda que apenas provisoriamente, tem vindo a ser reconhecida na ordem jurídica canadiana. Cfr. CAROL ROGERSON, The Canadian Law of Spousal Support, 38 Family Law Quarterly 69, 2004, p. 104-105.

Poderia, todavia, dizer-se que as teorias da "associação parental" se servem da obrigação de alimentos entre ex-cônjuges para incrementar a obrigação de alimentos perante os filhos e permitem, por outro lado, o estabelecimento de obrigações de longa duração e de montante elevado em casamentos de longevidade reduzida. 
Em suma, compreende-se a fragilidade da nova obrigação de alimentos entre ex-cônjuges numa cultura fundada na retórica da igualdade (formal) e na (pretensa) auto-suficiência ${ }^{63}$.

A relação matrimonial é considerada como uma comunhão de afectos fundada na igualdade e na liberdade, como uma associação de iguais. Apesar da neutralidade formal do ponto de vista do género, o termo é, todavia, enganador na medida em que os cônjuges não são, em geral, economicamente iguais ${ }^{64}$.

Surge a questão de se saber se os interesses presentes no divórcio são adequadamente tutelados e se os respectivos princípios traduzem uma base apropriada para o estabelecimento de compromissos entre posições aparentemente irreconciliáveis 65 .

Há que ter em conta algumas distinções fundamentais. Desde logo, aquela entre a partilha do património comum do casal e a obrigação de compensação ${ }^{66}$ e, depois, entre esta e a obrigação de alimentos.

\footnotetext{
A presença de filhos justifica o aspecto compensatório da obrigação de alimentos, reconhecendo-se as implicações económicas das responsabilidades parentais após a dissolução do casamento.

63 fr. GAYTRI KACHROO, Mapping Alimony: From Status to Contract and Beyond, in 5 Pierce Law Review 163, 2007, p. 169.

${ }^{64}$ Cfr. JENNIFER L. MCCOY, Comment: Spousal Support Disorder: An Overview of Problems in Current Alimony Law, in 33 Florida State University Law Review 501, 2005, p. 501.

65 Cfr. JUnE CARBone, The Futility of Coherence: The ALI's Principles of The Law of Family Dissolution, Compensatory Spousal Payments, in 4 Journal of Law $\&$ Family Studies 43, 2002, p. 45.

${ }^{66}$ A separação entre a noção de titularidade e a ideia de compensação por perda não equivale à distinção entre partilha do património comum do casal e obrigação de alimentos, porquanto a diferenciação entre ambas muito frequentemente suscita duas questões distintas: partilha de diferentes tipos de bens (e.g., bens de natureza tangível versus capacidade aquisitiva) e fundamentos diversos (e.g., contribuição para a formação do património comum versus perda). O termo "perda" corresponde a interesses normalmente reconhecidos no domínio da responsabilidade civil contratual e extracontratual, etc. Cfr. Margaret F. BRINIG/JUNE CARBONE, The Reliance Interest in Marriage and Divorce, in 62 Tulane Law Review 855, 1988; JUNE CARBONE, Economics, Feminism and the Reinvention of Alimony: A Reply to Ira Ellman, in 43 Vanderbilt Law Review 1463, 1990, p. 1472-1476.
} 
A lei separa a partilha do património comum do casal de outras questões patrimoniais, insiste na eliminação do conceito de culpa e desvaloriza a ideia de necessidade. Todavia, combina atribuições baseadas no conceito de contribuição com outras fundadas na noção de compensação e não suprime a ideia de culpa.

Enquanto a obrigação de compensação visa remover a perda de capacidade aquisitiva ou de capital humano sofrida por aquele cônjuge que, na vigência da sociedade conjugal, realizou uma contribuição para os encargos da vida familiar consideravelmente superior ao devido, a obrigação de alimentos visa remover a necessidade do cônjuge economicamente mais vulnerável. A irrelevância geral da culpa pela ruptura da sociedade conjugal no âmbito da obrigação de alimentos limita, necessariamente, o respectivo montante. Porém, a recuperação da ideia de culpa seria susceptível de implicar demasiados $\operatorname{custos}^{67}$.

Os princípios subjacentes ao casamento enquanto comunhão de vida baseada na liberdade e na igualdade, celebrado no regime da comunhão de adquiridos, justificam a partilha de todas as formas de riqueza adquiridas na vigência da relação matrimonial, a partilha de toda a riqueza acumulada a título oneroso na vigência da relação matrimonial, independentemente da forma de que concretamente se revista. A capacidade aquisitiva ou capital humano adquirido na constância da relação matrimonial, revestindo-se também de natureza patrimonial, deveria ser qualificado como bem comum do casal ${ }^{68}$. Com efeito, enquanto numa economia agrícola ou industrial, a maior parte da riqueza se consubstancia em bens tangíveis, na economia

67 Cfr. June CARbone, The Futility of Coherence: The ALI's Principles of The Law of Family Dissolution, Compensatory Spousal Payments, in 4 Journal of Law $\&$ Family Studies 43, 2002, p. 45.

68 Cfr. AliCIA BROKARS KELLY, Rehabilitating Partnership Marriage as a Theory of Welath Distribution at Divorce: In Recognition of a Shared Life, in 19 Wisconsin Women's Law Journal 141, 2004, p. 143. 
hodierna da informação e do conhecimento, a capacidade aquisitiva ou capital humano assume uma importância muito especial. Em virtude da metamorfose sofrida pelo património, o impacto da capacidade aquisitiva ou capital humano afigura-se particularmente relevante no âmbito das consequências patrimoniais do divórcio.

$O$ respeito pela ideia do casamento enquanto comunhão pessoal e patrimonial fundada na liberdade e na igualdade pressupõe o tratamento da capacidade aquisitiva como bem comum do casal, adaptando as regras da partilha às especificidades do bem em causa. Em muitos casamentos, o capital humano constitui o único bem economicamente relevante adquirido na sua vigência ${ }^{69}$. O desenvolvimento da carreira profissional é, muito frequentemente, um dos projectos mais importantes empreendidos pelos cônjuges. A não inclusão da capacidade aquisitiva no património comum do casal distorce a regra da partilha em partes iguais. Acresce que, quando se trata do cônjuge mulher, a exclusão do capital humano do património comum do casal produz efeitos perversos na almejada igualdade dos géneros ${ }^{70}$.

O paradigma do casamento como associação de iguais justifica pois a partilha de toda a riqueza acumulada na vigência da relação matrimonial, independentemente da respectiva forma ${ }^{71}$. Se assim

69 Cfr. Carolyn J. Frantz/HANOCH DAgAn, Properties of Marriage, in 104 Columbia Law Review 75, 2004, p. 108.

70 Cfr. Allen M. PARKMan, No-Fault Divorce: What Went Wrong?, Westview Press, Boulder, Colo, 1992, p. 7-28. A desconsideração do capital humano dos cônjuges pelo regime patrimonial do casamento contribui para a deterioração da situação económica do ex-cônjuge mulher e para a desigualdade dos cônjuges, cfr. Deborah L. RHODE/MARTHA MINOW, Reforming the Questions, Questioning the Reforms: Feminist Perspectives on Divorce Law, in Divorce Reform at the Crossroads, (edited by Stephen D. Sugarman/Herma Hill Kay), Yale University Press, New Haven, 1990, p. 200; JOAN C. WILlimas, Women and Property, in A Property Anthology (Richard H. Chused ed.), Anderson Publishing Company, Inc., Cincinnati, 1997, p. 258-59.

${ }^{71}$ Está em causa a possibilidade de gerar rendimento. Cfr. ALICIA BROKARS KelLy, Rehabilitating Partnership Marriage as a Theory of Welath Distribution at Divorce: In Recognition of a Shared Life, in 19 Wisconsin Women's Law Journal 141, 2004, p. 165. 
não for, do novo direito do divórcio não resulta uma igualdade económica para as mulheres.

Malogradamente, o legislador não aproveitou a oportunidade da reforma para redefinir os bens que integram o património comum do casal e, por isso, não leva em conta os efeitos do casamento na capacidade aquisitiva ou capital humano de cada um dos cônjuges ${ }^{72}$. Subsiste uma noção estática e monolítica de património, a assim denominada "mitologia do património"73, apoiada porventura em fantasmas exegéticos, que ignora aqueles direitos patrimoniais que não se subsumem àquele paradigma de património ${ }^{74}$.

Tão relevante como a regra da partilha do património comum em partes iguais é a da determinação dos bens sujeitos a essa regra. Está em jogo o objectivo prático da constituição do património comum do casal. A regra da partilha em partes iguais não cumpre o respectivo objectivo no caso de se excluírem bens relevantes dessa mesma partilha.

72 Cfr. Allen M. PARKMan, Property Settlements as the Cornerstone of Financial Arrangements at Divorce, in 4 Journal of Law \& Family Studies 117, 2002, p. 126.

73 Cfr. Milton C. REGAN, Jr., Spouses and Strangers: Divorce Obligations and Property Rhetoric, in 82 The Georgetown Law Journal 2303, 1994, p. 2309-10. Aquela "mitologia do património" "projects... property rights as absolute, alienable, inheritable, and exchangeable on the open market". Cfr. JOAN WILliAMS, Is Coverture Dead? Beyond a New Theory of Alimony, in 82 The Georgetown Law Journal 2227, 1994, p. 2271.

${ }^{74}$ Cfr. Milton C. Regan, Jr., Spouses and Strangers: Divorce Obligations and Property Rhetoric, in 82 The Georgetown Law Journal 2303, 1994,

p. 2318-2319; JOAN WILliAMS, Is Coverture Dead? Beyond a New Theory of Alimony, in 82 The Georgetown Law Journal 2227, 1994, p. 2271. 
(Página deixada propositadamente em branco) 